\title{
Evaluating the Income and Employment Impacts of Gas Cooling Technologies
}

\author{
by \\ P. J. Hughes \\ Oak Ridge National Laboratory \\ and \\ S. Laitner \\ Economic Research Associates
}

March 1995

Prepared by the

OAK RIDGE NATIONAL LABORATORY

managed by

MARTIN MARIETTA ENERGY SYSTEMS, INC.

Oak Ridge, Tennessee 37831-2008

for the U.S. Department of Energy

under Contract No. DE-AC05-84OR21400

OISTRIBUTION OF THIS DOCUMENT IS UNLMITED WW 



\section{DISCLAIMER}

This report was prepared as an account of work sponsored by an agency of the United States Government. Neither the United States Government nor any agency thereof, nor any of their employees, make any warranty, express or implied, or assumes any legal liability or responsibility for the accuracy, completeness, or usefulness of any information, apparatus, product, or process disclosed, or represents that its use would not infringe privately owned rights. Reference herein to any specific commercial product, process, or service by trade name, trademark, manufacturer, or otherwise does not necessarily constitute or imply its endorsement, recommendation, or favoring by the United States Government or any agency thereof. The views and opinions of authors expressed herein do not necessarily state or reflect those of the United States Government or any agency thereof. 


\section{DISCLAIMER}

Portions of this document may be illegible in electronic image products. Images are produced from the best available original document. 


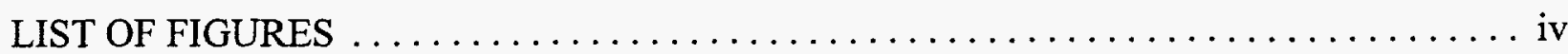

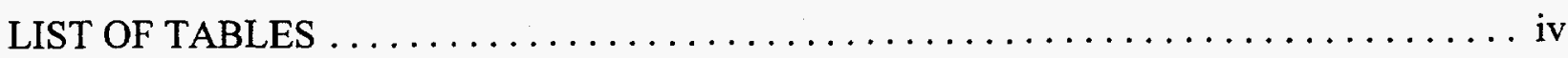

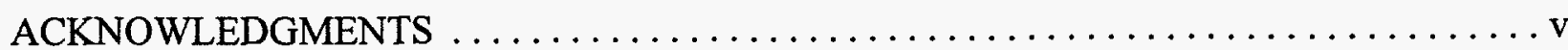

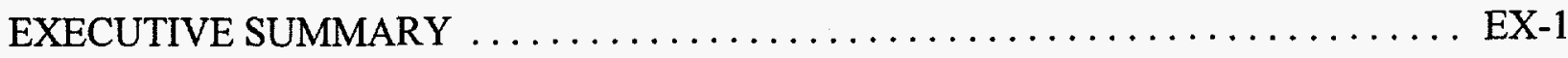

PROJECTED GAS COOLING EXPORTS $\ldots \ldots \ldots \ldots \ldots \ldots \ldots \ldots \ldots \ldots \ldots \ldots \ldots \ldots$

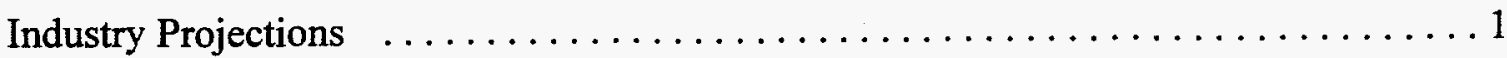

Are The Industry Projections Possible? . . . . . . . . . . . . . . . . . . . . . . 1

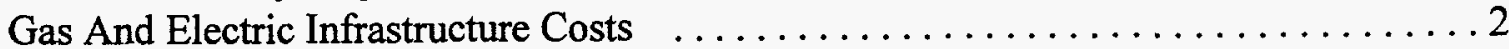

Do Gas Infrastructure Developments Support The Industry Projections? . . . . . . . . 3

Gas Cooling Export Projections Used In This Study .................... 5

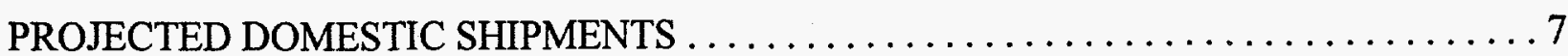

Reference Case Equipment Shipments Out to $2010 \ldots \ldots \ldots \ldots \ldots \ldots \ldots \ldots \ldots$

Gas Cooling Scenario Equipment Shipments Out to $2010 \ldots \ldots \ldots \ldots \ldots \ldots \ldots$

SUMMARY DESCRIPTION OF GAS COOLING SCENARIO $\ldots \ldots \ldots \ldots \ldots \ldots \ldots 14$

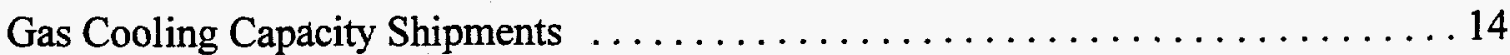

Customer Bill Savings Attributable To Gas Cooling $\ldots \ldots \ldots \ldots \ldots \ldots \ldots \ldots$

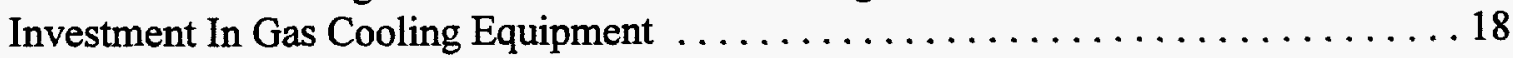

Customer Payback on Gas Cooling Investments . . . . . . . . . . . . . . . 18

Potential Impact on Electric and Gas Utilities . . . . . . . . . . . . . . . . . 19

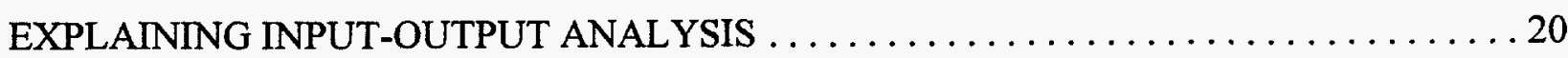

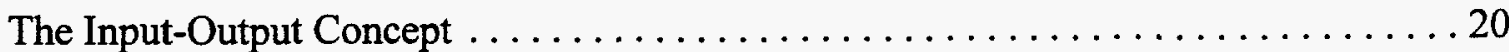

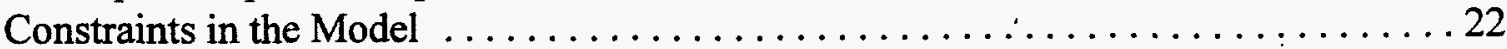

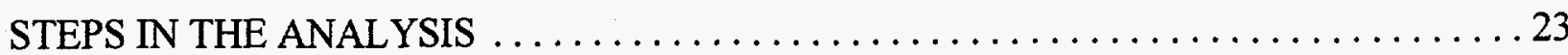

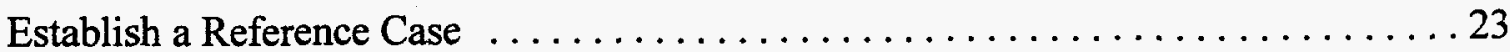

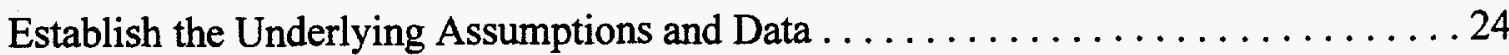

Establish the Gas Cooling Scenario ............................. 24

Design Spreadsheet Input-Output Model . . . . . . . . . . . . . . . . . . . 24

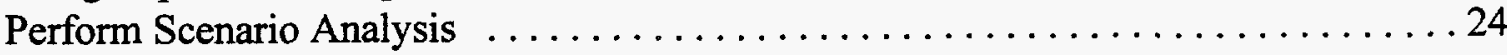

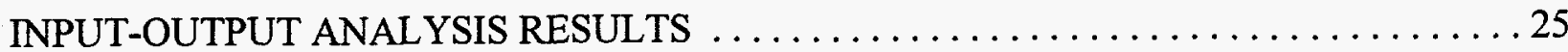

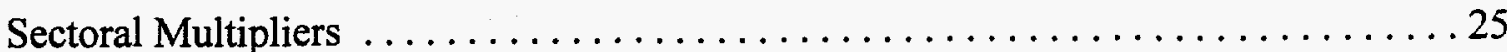

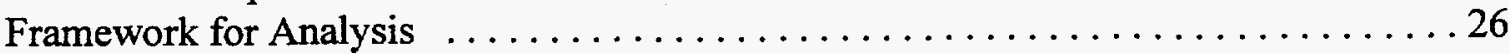




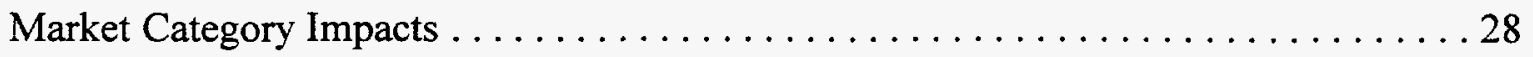

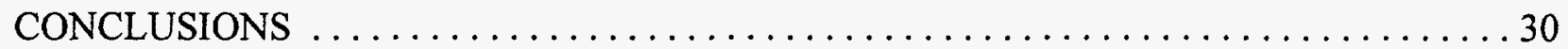

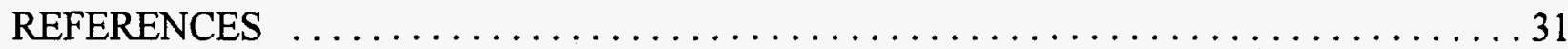

APPENDIX A: SUPPLEMENTAL ASSUMPTIONS AND DATA $\ldots \ldots \ldots \ldots \ldots$ A-1

Typical Size and Type of Gas Cooling Units That Will Be Installed ........... A-1

Typical Conventional Electric Cooling Equipment Displaced By Gas Cooling ..... A-3

Costs Relative to Conventional Systems . . . . . . . . . . . . . . . . . A-4

Life of Gas Cooling Equipment $\ldots \ldots \ldots \ldots \ldots \ldots \ldots \ldots \ldots \ldots \ldots \ldots \ldots \ldots$

\section{LIST OF FIGURES}

Fig. 1. Projected total domestic gas cooling capacity shipments $\ldots \ldots \ldots \ldots \ldots \ldots \ldots \ldots$

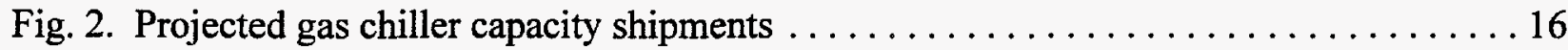

Fig. 3. Customer bill savings attributable to gas cooling $\ldots \ldots \ldots \ldots \ldots \ldots \ldots \ldots \ldots \ldots \ldots$

Fig. 4. Customer simple payback on gas cooling investments $\ldots \ldots \ldots \ldots \ldots \ldots \ldots \ldots$

Fig. 5. Electricity generating capacity avoided by gas cooling $\ldots \ldots \ldots \ldots \ldots \ldots$

\section{LIST OF TABLES}

Table 1. Multipliers for key economic sectors (1989 constant dollar basis) $\ldots \ldots \ldots \ldots \ldots 25$

Table 2. Summary impacts from domestic residential gas cooling shipments . . . . . . . . 29

Table 3. Summary impacts from domestic commercial gas cooling shipments . . . . . . . . . 29

Table 4. Summary impacts from gas cooling exports $\ldots \ldots \ldots \ldots \ldots \ldots \ldots \ldots \ldots \ldots$ 


\section{ACKNOWLEDGMENTS}

The authors gratefully acknowledge the direct support of the U.S. Department of Energy, Energy Efficiency and Renewable Energy, Office of Building Technologies, and the American Gas Cooling Center. The authors would also like to thank the many people who contributed to this work. S. W. Hadley and S. R. Elliott of the Energy Division of Oak Ridge National Laboratory (ORNL) performed the commercial sector energy rates analysis. A. J. Brown and S. R. Simmons, both University of Tennessee students who interned at ORNL, performed the residential sector energy rates analysis. S. Carlson, H. Henderson, and R. Hough, all with The Fleming Group at the time of this work, automated market assessment methodologies developed at ORNL for the residential, small commercial, and large commercial building markets. Lastly, the authors would like to thank P. D. Fairchild, G. E. Courville, R. C. DeVault, J. J. Tomlinson, and D. P. Vogt for reviewing this report and providing constructive comments. 


\section{EXECUTIVE SUMMARY}

The purpose of this study is to estimate the potential employment and income benefits of the emerging market for gas cooling products. The emphasis here is on exports because that is the major opportunity for the U.S. heating, ventilating, and air-conditioning (HVAC) industry. But domestic markets are also important and considered here because without a significant domestic market, it is unlikely that the plant investments, jobs, and income associated with gas cooling exports would be retained within the United States.

The prospects for significant gas cooling exports appear promising for a variety of reasons. There is an expanding need for cooling in the developing world, natural gas is widely available, electric infrastructures are over-stressed in many areas, and the cost of building new gas infrastructure is modest compared to the cost of new electric infrastructure. Global gas cooling competition is currently limited, with Japanese and U.S. companies, and their foreign business partners, the only product sources. U.S. manufacturers of HVAC products are well positioned to compete globally, and are already one of the faster growing goods-exporting sectors of the U.S. economy. Net HVAC exports grew by over 800 percent from 1987 to 1992 and currently exceed $\$ 2.6$ billion annually (ARI 1994).

Net gas cooling job and income creation are estimated using an economic input-output model to compare a reference case to a gas cooling scenario. The reference case reflects current policies, practices, and trends with respect to conventional electric cooling technologies. The gas cooling scenario examines the impact of accelerated use of natural gas cooling technologies here and abroad.

The gas cooling scenario is based on aggressive pricing of gas heat pumps and chillers. Such pricing may come from manufacturers intent on building their global businesses. The estimated domestic market share would result in about $290 \mathrm{BCF}$ of additional natural gas use in U.S. residential and commercial buildings by 2010 . For comparison, gas industry estimates range as high as $800 \mathrm{BCF}$ by $2010,500 \mathrm{BCF}$ directly attributable to cooling and $300 \mathrm{BCF}$ in other loads that would be lost without cooling (Gas Utility Report, 9/2/94). The export estimates are based on manufacturer's projections as reported in a previous study (Geletka and Cobb, 1993) and qualitative analysis of energy infrastructure developments outside of the U.S.

Job and income creation due to domestic gas cooling shipments are estimated net of secondary effects such as displaced conventional HVAC equipment, reduced electric consumption, and increased gas consumption. The estimated job and income creation due to exports assumes that exports displace products manufactured in other nations. Global gas cooling markets exist and, in the absence of American competition, these markets will be exclusively served by Japanese companies and their foreign business partners.

We estimate that the gas cooling scenario would create a net of 626,000 job-years of new employment and about $\$ 5.7$ billion (1993 dollars) in net exports during the 1996 to 2010 analysis 
period. The average employment gain over the 15 years is 41,700 jobs $(626,000$ divided by 15$)$, of which about 10,400 are the result of exports. The employment gain in 2010 is about 100,000 jobs.

We also estimate that in 1993 dollars, the gas cooling scenario would create $\$ 14.7$ billion in new wage and salary income through 2010, for an average of $\$ 979$ million annually ( $\$ 4.7$ billion divided by 15), or about $\$ 23,500$ annually per job. Also in 1993 dollars, the wage and salary gain in 2010 is $\$ 2.2$ billion, or about $\$ 22,000$ annually per job.

In addition to wage and employment benefits, the gas cooling scenario avoids $18.3 \mathrm{GW}$ of domestic electric generation capacity, lowers domestic residential and commercial customer utility bills by $\$ 17.6$ billion (1993 dollars), and expands domestic HVAC markets by $\$ 3.3$ billion (1993 dollars) cumulatively through the year 2010 .

The U.S. continues to build a strong base of intellectual property and international patent protection in several gas cooling technologies. Although this has been accomplished largely through gas industry and public investment, recently formed partnerships have now also attracted HVAC industry investment in a number of technologies.

Realization of the estimated job and income benefits will require aggressive development and marketing of reliable products with market-clearing price and performance characteristics. Although the manufacturers involved with gas cooling technologies believe it is possible to reach the product selling prices used in the analysis, this has yet to be proven. Higher priced gas cooling products would win less market share here and abroad, create correspondingly fewer job and income benefits, and each unit of benefit would require greater societal investment than the current analysis indicates. 


\section{PROJECTED GAS COOLING EXPORTS}

This section summarizes the basis for the gas cooling export projections used in the gas cooling scenario.

\section{$\underline{\text { Industry Projections }}$}

The University of Pittsburgh (Geletka and Cobb 1993) recently completed a study of gas cooling export potential. As part of the study, the authors polled three large domestic equipment manufacturers and documented the average of their absorption chiller export projections for the period 1995 through 2004. While absorption exports to Europe and Africa were expected to rise to $\$ 50$ million annually by 1995 and then remain relatively flat, exports to Mexico, Central and South America, and Asia were expected to explode to an additional $\$ 50$ million by 1995 and to $\$ 300$ million by 2004. If these projections are correct, absorption chiller exports would have to grow from 1993 levels of about \$8 million to about \$100 million in 1995 and about \$360 million in 2004.

\section{Are The Industry Projections Possible?}

To substantiate whether such growth rates were possible, the Pittsburgh study examined the potential cooling markets in less-developed countries. The roughly 100 countries recognized as less developed by the World Bank were screened for having a climatic need for cooling; having the political stability and organization necessary for energy infrastructure data to be available and collected by the Energy Information Administration (EIA); and having gas available and gas infrastructure existing, under construction, or planned. A total of 34 countries met these criteria. By considering only floor space additions due to new construction of commercial, health, and medical facilities in these 34 countries, the Pittsburgh study estimated that over 5 million tons of cooling capacity annually would be required in the projection time frame. At $\$ 300$ per ton for absorption equipment at point of export (approximately FOB factory in 1993), that would be a $\$ 1500$ million annual market. Gas cooling exports of $\$ 360$ million would be $24 \%$ of that market, or a smaller share of the total market if all building types had been accounted for.

In considering whether a $20 \%$ or so share of the developing world cooling market is realistic for gas cooling, it is useful to review some of the findings in a recent article in Technology Review written by a senior researcher at Worldwatch Institute (Lenssen 1993). There are 4 billion people in Africa, Asia, and Latin America striving to improve their lives. Through a combination of efficiency and alternative energy sources, developing countries can "leapfrog" to the advanced technologies being commercialized in industrial countries today, avoiding billions of dollars of misdirected investments in infrastructure that is economically and environmentally obsolete. Many developing countries have extensive untapped reserves of natural gas, which could supplant oil and coal in buildings, transport, industry, and power generation. When international oil companies operating in developing countries find natural gas in an exploratory well, they usually cap the well and write the venture off as a tax loss. Yet a natural gas well just one-hundredth the size needed for commercial export would be cost-effective for local use. The key is building the infrastructure needed to bring natural gas to 
the large markets awaiting it. Substantial reserves of natural gas have already been found in some 50 developing countries. Many of the oil-producing and exporting countries have burned off (flared) gas as a waste byproduct of petroleum production without capturing any useful energy. In Nigeria, for instance, several oil producers burn as waste a total of 1.5 billion $\mathrm{ft}^{3}$ of gas a day-equal to $3 \%$ of U.S. demand (Solomon 1994).

Lenssen observes that many developing countries are still contending with shortages of electricity. India's shortfall averages $9 \%$, rises to $22 \%$ during peak periods, and is worsening. China's shortfall results in regular shutdowns of industry; it idled one-fourth of the country's industrial capacity in 1987. Electricity shortages are costing Latin America's industry as much as $\$ 15$ billion per year in lost output. And 2.1 billion people worldwide live in areas with no electricity at all.

\section{Gas And Electric Infrastructure Costs}

According to a recent survey of current and planned natural gas infrastructure construction outside of the United States and Canada (Ives 1993), about 52\% of the current construction activity and 56\% of the planned activity is in the Asian and Latin American areas where the greatest gas cooling growth is anticipated. The survey indicates that much of the gas pipeline construction activity in the developing world is initially aimed at serving liquified natural gas (LNG) export terminals and domestic industrial and power generation needs. But the difference in costs between electric infrastructure and gas infrastructure to serve a wide variety of end-uses is not likely to go unnoticed. Here in the United States, the ratebase (plant less depreciation) required to deliver energy to customers in the form of electricity is about 10 times higher than the ratebase to deliver the same energy in the form of natural gas (EIA 1991; AGA 1991). Ratebase is a measure of historical costs. In a forward-looking integrated resource planning context, the 10-to-1 ratio appears also to hold for the case of obtaining additional peak-day supplies of electricity or gas for applications already connected to the electric and gas grids (Kaul and Kihm 1992).

Developing countries using export cash flows (e.g., from LNG exports) to attract financing for domestic development will be looking to avoid billions of dollars of misdirected investments. Electricity is a highly processed and expensive form of energy that cannot be stored easily, and it is unlikely that the developing world will rely exclusively on electric cooling with its associated load peaks and low-system-load factors. The cost to lay additional increments of gas distribution pipe in urban areas to accommodate gas cooling (and heating, hot water, cooking, industrial use, etc.) is likely to be far less expensive than the avoided electric infrastructure costs to serve all of these needs with electricity. In addition, the electric infrastructure that is actually built would be able to run at highly economical load factors. 


\section{Do Gas Infrastructure Developments Support The Industry Projections?}

The Ives survey and observations by A.D. Little in a survey for the U.S. Department of Energy (ADL 1993) appear to confirm that the trend in energy infrastructure development overseas is toward increased emphasis on natural gas. This trend supports the equipment manufacturer projections of growing export potential for gas cooling equipment. A summary of Asian, Latin American, and other gas infrastructure developments is provided below.

Asian gas infrastructure. Japan is the second largest market in the world (after the U.S.) for cooling equipment, far ahead of the next largest. More than 50 percent of residences in Japan are connected to the gas grid; in some utility service areas (e.g., Osaka Gas, Tokyo Gas), more than 80 percent are connected. A similarly high percentage of commercial buildings are connected. Japanese production of gas-fired absorption chiller units exceeds that of the U.S. by a factor of 10 , and currently 90 percent are placed domestically. Gas heat pumps were introduced in Japan in 1987 and 100,000 units were placed through the end of 1991. In the service territory of Osaka Gas, over 70 percent of the chiller capacity placed in large buildings (greater than $86,000 \mathrm{ft}^{2}$ ) in 1991 was gasfired (Ueda 1993). The gas grid in Japan is supplied primarily by LNG imports and subsea pipelines.

Taiwan already has an extensive urban gas grid reaching residential and commercial customers. This grid is served by LNG imports, and expansion of the Yungan LNG receiving terminal is planned. South Korea has an extensive urban gas grid under construction in the central and west coast regions and recently enacted a regulation requiring new large commercial buildings to use either absorption chillers or thermal storage to reduce peak electric utility loads. The Korean grid is served with LNG imports from Malaysia, and steps are being taken to diversify supplies (from Australia, Yemen, Qatar). In Viet Nam construction is either under way or planned to start in 1994 on three natural gas supply lines (subsea pipelines from Bach Ho field and Erawan field to landfall, and from Bachtto to Vuns Tu).

Malaysia's LNG export terminals are in the East, but the domestic demand is in Peninsular Malaysia. The Peninsular Gas Utilization project will connect gas fields offshore of Terenganu to markets all over Peninsular Malaysia and Singapore. Construction has begun on Singapore to connect Johor Strait and Queenstown, Toh Tuck, and Kallang districts to the new Malaysian supplies. In Thailand a residential/commercial gas grid in Bangkok is under development and is expected to be in place in 1996. The Petroleum Authority of Thailand is moving forward with plans to establish a national gas grid connecting offshore Erawan field supplies to Khonom District, connecting Nam Phong field to Bangkok and Saraburi, and establishing connections to Khonkaen and Chon Buri Provinces.

In Indonesia there are large potential gas demands in Java and Jakarta. Stage I of the Trans-Java gas pipeline project between the demand centers and indigenous supplies is under way, and the entire project should be completed in the late 1990s. Construction is close to starting on a subsea gas pipeline from China's Yacheng field offshore from Hainan Island to Hong Kong, 480 miles away (the second longest pipeline in the world after Zeepipe in the North Sea). China continues to look 
at a national distribution grid and related facilities that would measure up to 4,400 miles. The grid, covering several provinces, would move both natural gas and regasified LNG. Australia's future plans call for nearly 4,800 miles of new natural gas lines as the country seeks to expand the national grid to develop competitive energy prices and serve export markets.

India has initiated an aggressive campaign to eliminate gas flaring in its oil production regions. A subsea gas pipeline is under construction from the offshore Bassein field to a terminal near Bombay, and another has been approved. India's Gas Authority has proposed a national gas grid linking the North, West, South, and East regions of the country (over 11,400 miles of pipe). Final planning for New Delhi's gas distribution system and for a link between the Godavari Basin fields and Kikinada is under way. Bangladesh is considering some 1,500 miles of gas transmission and distribution pipeline ranging in size from 2 in. to 14 in., which is aimed at fostering the country's industrial and economic growth.

Latin American gas infrastructure. In addition to Asia, the other major gas cooling growth area is likely to be in Latin America. Here too, gas infrastructure development appears to be accelerating. Mexico already has considerable gas infrastructure and plans an additional 350 miles of pipeline in the next 5 years. Mexico's major new markets for gas in this period are in the North, particularly across from California. These needs are expected to be met with new U.S. lines transporting U.S. and Canadian gas.

This year's privatization initiatives by the government promise to make Argentina a major consumer and exporter of natural gas in the near future. Financing for the Argentina-Chile pipeline system is expected to be resolved shortly. The 740-mile pipe will cross the Andes and connect Argentina's Neuquen province fields to a distribution network in Chile that will serve Santiago initially. Export lines to Brazil, Uruguay, and Paraguay are also under study.

Bolivia and Brazil have reached agreement on transporting natural gas from southeast Bolivia to consuming regions of Brazil. The total project calls for about 2200 miles of pipe and initial deliveries starting in 1997. There already are extensive gas grids in Rio de Janeiro and Sao Paulo, and grid expansions are expected in other cities in the south and southeast. The natural gas exports will more than double the revenues of Bolivia, providing resources to support Bolivian economic development.

Columbia is making a major push for gas utilization, featuring pipeline and other facility construction reaching $\$ 3$ billion by the year 2015 . Gas use will extend to power generation, industrial, commercial, residential, and vehicular uses. The state-owned Ecopetrol will oversee most of the activity. Ecopetrol envisions a gas network from the north coast to central Columbia, as well as a series of regional lines. Some segments are scheduled for completion in 1994 and 1995. Gas supplies associated with both domestic oil fields and imports are envisioned. Venezuela is considering proposals for a pipeline to export gas to Columbia. Also, the government recently approved the construction of an LNG export terminal for gas supplied from four gas fields in the Caribbean Sea north of Paria Peninsula. 
Other areas of the world. Other areas of the world besides Asia and Latin America are also experiencing rapid gas infrastructure development. Expanding demands for clean-burning fuels in Europe are driving construction of natural gas pipelines from the former Soviet Union (FSU), North Africa, and the North Sea. The greatest activity is in the North Sea, where Zeepipe Phase I is wrapping up, and Zeepipe II, Europipe, and Haltenpipe are under way.

Increased pipelining in Africa is closely tied to natural gas expansion in Europe. Algeria has transMediterranean loop construction to Italy under way and has started engineering its part of the Maghreb-Europe system that will transport gas from Algeria to Spain, Portugal, and eventually France and Germany. Libya is in a position to tie in its production.

Most of the countries of Western Europe have well developed gas grids, but a few are catching up now. Denmark plans a 2,400-mile expansion of its gas distribution system. Germany has several expansions under way, including a new system to supply gas to the former East Germany from the FSU and the West. Much of the planned activity in Eastern Europe and the FSU appears to be delayed by political and economic instability.

The Mideast oil-exporting nations are beginning to place greater emphasis on seeking domestic and export markets for gas. Abu Dhabi has nearly 300 miles of pipe scheduled for completion in 1995 and 1996 that will provide links from Habshan to Ruwais, Bab to Miffa, Bab to Taweelah, and Maqta to Taweelah. Iran will complete a line from Neka to Resht in 1994 and has another planned from Dalan to Khuzestan. Iran is also considering enormous pipeline projects to export gas to Pakistan and Turkey. Oman is planning a 900-mile subsea pipe to India, as well as LNG exports. Qatar is expanding gathering lines to feed its Ras Laffan LNG export terminal and is studying a 995mile subsea pipe to Pakistan. Syria is constructing gas gathering lines to fuel power plants with domestic gas supplies. Egypt is expanding its gas grid, particularly in Cairo, to reach an additional 235,000 houses and 5,000 commercial and industrial customers.

\section{Gas Cooling Export Projections Used In This Study}

There appears to be considerable evidence that gas infrastructure construction in the developing world can support gas cooling equipment export growth similar to that projected by industry. Particularly in Asia, many cities already have low-Btu town gas systems (gas derived from coal) that can be served with natural gas as it becomes available. Only the United States and Japan manufacture and sell significant quantities of gas cooling equipment, whereas many other nations (South Korea, Taiwan, Malaysia, China, many European countries) have considerable domestic production of electric cooling equipment (primarily small unitary equipment). The growth markets for cooling equipment are in the developing world, where electric infrastructure must also grow. Avoided electric supply costs more than make up for the cost premium of gas cooling equipment. Most gas cooling equipment can run on oil, propane, or regasified LNG and therefore can be placed in service before robust electric or gas infrastructures exist, and then inexpensively converted to natural gas when the pipeline is laid. This provides ready-made loads, making it easier to finance pipeline projects. Gas cooling equipment gives developing countries a competitive edge by 
minimizing their overall capital requirements and by making it easier for them to secure the capital they need to develop their economies.

The Japanese will be formidable competitors for this growing market, particularly since many of the growth markets are in Asia. But the United States appears on the verge of creating a technology edge with the new direct-fired triple-effect absorption chillers and engine-driven chillers (versus the less efficient direct-fired double-effect absorption chillers), and absorption and engine-driven gas heat pumps (versus the more expensive engine-driven units based on motorcycle engines). Creating and exploiting a technology edge will be a key to succeeding in the global competition. The export projections used in this report are bounded by current import/export levels in the near term and, in the case of chillers, by the industry forecast in the long run. For chillers, the ramp up assumed here is slower than the industry forecast. The rationales for unitary and chiller export projections follow.

The closest equipment category to unitary gas cooling imports/exports in 1992 was the small absorption category (Commerce 1994). The imports are primarily small packaged absorption liquid chillers from Japan, and the exports are primarily small split-system absorption air conditioners to Europe. In 1992, imports were valued at about $\$ 5$ million and exports at $\$ 8$ million.

The overseas markets for unitary gas heat pumps will likely be in areas with significant space heating as well as cooling requirements, and with well developed gas grids connected to residential and commercial customers. Most of the Asian markets have tropical or subtropical climates with limited need for heating, Japan and Korea being notable exceptions. Latin American opportunities exist in high altitude regions, and in areas further south such as southern Brazil and Argentina. European opportunities for equipment configurations that condition air may be limited because of the mild cooling climate and the prevalence of hydronic distribution systems for space heating. But a heating-only hydronic configuration would have opportunities in Germany and elsewhere. Opportunities in the FSU and Eastern Europe may be enormous because of the extreme climates (heating, and in some cases cooling), plentiful gas, and considerable gas infrastructure; but these opportunities will likely be delayed by continuing political and economic unrest. Efficient and modestly priced cooling-only configurations would have enormous potential in many parts of Asia, Latin America, Africa, the Middle East, and Southern Europe.

All things considered, it is reasonable to believe that unitary gas cooling exports could grow into a $\$ 400$ million per year business by 2010 . If we split this market with the Japanese, our share would grow to $\$ 200$ million per year. It is assumed that by 1996 domestic manufacturers will reclaim the entire domestic market so that there are no unitary imports in the base case. In addition, it is assumed that exports grow from $\$ 8$ million to $\$ 10$ million by 1996 . The shape of the export growth curve from $\$ 10$ to $\$ 200$ million in the 1996-2010 timeframe is based on judgment consistent with what is assumed to be happening in the domestic markets. It is further assumed that the dollar value of unitary exports will be equally divided between 3-ton and 7.5-ton units. The point of export valuation was assumed to be FOB factory. By using the same FOB factory assumptions as for the domestic shipments from 1996 through 2010, the number of 3-ton and 7.5-ton units was backed out and is presented in the following table for the three 5-year periods. 


\begin{tabular}{cccc}
\hline Type & \multicolumn{3}{c}{ Number of units per 5-year period } \\
\hline & $1996-2000$ & $2001-2005$ & $2006-2010$ \\
3-ton gas heat pump exports & 8,900 & 39,500 & 53,300 \\
7.5-ton gas heat pump exports & 3,893 & 18,160 & 25,040 \\
\hline
\end{tabular}

The overseas markets for chiller-class gas cooling equipment are based in part on the Pittsburgh study, which indicated a potential $\$ 1500$ million annual market from 1995 to 2004 based on a limited number of building types in less-developed countries. Manufacturers are projecting $\$ 360$ million in exports in 2004 , or a $24 \%$ share. In Japan, gas cooling has about a $70 \%$ share of the market in large buildings in areas served by aggressive gas companies such as Osaka Gas (Ueda 1993). In this study, we are projecting about a $24 \%$ gas cooling share domestically in the United States chiller markets in 2004. The developing countries are generally short of financing, and a gas cooling share closer to that of Japan is likely, say $50 \%$. If we split this export opportunity with Japan, that gives $25 \%$, or about what industry is projecting. If $\$ 360$ million is the value of sales in 2004 , we assume that $\$ 400$ million is the value in 2010 .

In the gas cooling scenario, we assume that gas chiller exports of all types grow to $\$ 10$ million by 1996 and $\$ 400$ million by 2010 . In 1993 about $\$ 8$ million in absorption chillers were manufactured in the United States and exported (Commerce 1994). This amount is smaller than the uncertainty associated with the gas cooling scenario export projections, and therefore exports are ignored in the reference case. Summary exports by the three 5-year periods are as follows:

\begin{tabular}{cccc}
\hline Type & \multicolumn{3}{c}{ 1000s of tons per 5-year period } \\
\hline & $1996-2000$ & $2001-2005$ & $2006-2010$ \\
Gas chiller exports (all types) & 197 & 1017 & 1312 \\
\hline
\end{tabular}

\section{PROJECTED DOMESTIC SHIPMENTS}

This section summarizes the basis for the domestic shipment projections used in the reference case and the gas cooling scenario.

\section{Reference Case Equipment Shipments Out to 2010}

Residential unitary. The primary gas cooling option in this market is the gas heat pump, a device that provides both space heating and cooling. Therefore the reference case "electric" equipment 
shipments of interest are either equipment combinations (gas furnaces and electric air conditioners) or devices (electric heat pumps) that perform both heating and cooling.

This study relies on a previously completed market assessment to establish the reference case equipment shipments for the 1996-2000 period (Carlson et al., 1994). The 2001-2005 and 2006-2010 shipments were projected based on previous analyses of replacement markets (Lewis and Clarke 1990a), and assuming flat new-construction shipments through 2010. Shipments are stated as average annual shipments over a 5 -year period in recognition that annual shipments are highly dependent on the business cycle and can vary widely from year to year. The resulting projections are summarized as follows:

\begin{tabular}{lrrr} 
Unit/Yr & $1996-2000$ & $2001-2005$ & $2006-2010$ \\
\hline Gas furnace/air conditioner combos & $1,800,000$ & $1,948,000$ & $2,140,000$ \\
Air-source electric heat pumps & 500,000 & 553,000 & 613,000 \\
\cline { 2 - 4 } Total & $2,300,000$ & $2,501,000$ & $2,753,000$
\end{tabular}

The furnace/air conditioner combinations are a subset of projected furnace and air conditioner shipments. For example in 1996-2000, average annual shipments of gas warm-air furnaces and electric central air conditioners are expected to be 2.4 million and 3.1 million, respectively; but only 1.8 million combinations of the two are expected. Only $50 \%$ of the expected electric heat pump shipments are listed, corresponding to the approximate number of applications contestable by gas heat pumps (most new construction is up for grabs, but in replacement applications, gas is not available everywhere). Other central ducted systems (e.g., ground-source heat pumps, dual fuel heat pumps) that could be contested by gas heat pumps number about 200,000 units per year in 1996-2000 but were not considered here. Central hydronic and room unit applications were ignored altogether.

Commercial Unitary. The primary gas cooling option in this market is the gas heat pump. The typical configuration is the packaged rooftop unit, although split systems will also be offered. The reference case "electric" equipment shipments of interest are conventional gas furnace heat/electric cool units, electric resistance heat/electric cool units, and electric heat pump units (backed up by resistance heat) of 20 to 25 tons or less.

The previous market assessment (Carlson 1994) established the reference case equipment shipments for the 1996-2000 period. Again, the 2001-2005 and 2006-2010 shipments were projected based on previous analyses of replacement markets (Lewis and Clarke 1990b) and assuming flat newconstruction shipments through 2010. The resulting projections are as follows: 


\begin{tabular}{lrrr} 
Unit/Yr & $1996-2000$ & $2001-2005$ & $2006-2010$ \\
\hline Gas/electric & 540,000 & 679,000 & 952,000 \\
Electric/electric & 90,000 & 91,000 & 92,000 \\
Electric heat pump & 70,000 & 98,000 & 117,000 \\
\cline { 2 - 4 } Total & 700,000 & $\mathbf{8 6 8 , 0 0 0}$ & $1,161,000$
\end{tabular}

Only $50 \%$ of the electric/electric and electric heat pump shipments are listed, corresponding to the approximate number contestable by gas cooling. These shipments represent units of about 25 tons or less; the average shipment weighted size is about 7.5 tons. Unit volume in larger sizes is low and may only support custom gas cooling products serving niche markets.

Chillers. The gas cooling entrees in this market are water-cooled, direct-fired double-effect and triple-effect absorption chillers, and engine-driven chillers. The typical configuration is a multichiller plant with a mix of electric and gas chillers. The reference case "electric" equipment shipments of interest are water-cooled electric centrifugal and screw chillers that range in size from about 100 to 3000 tons.

A previous market assessment (MacDonald, Hughes, and McLain 1992) estimated that 21 million tons of electric water-cooled chillers would be shipped from 1996-2010 to domestic markets. A previous analysis of replacement markets (Lewis and Clarke 1990b) shows replacements peaking in the 1996-2000 period and declining somewhat thereafter. Combining these projections and assuming flat shipments to new construction results in the first line of the following projections.

However, since these studies were completed, chlorofluorocarbon (CFC) production has been mandated to end by January 1996. In round figures, the installed base of centrifugal chillers is 40 million tons and 80,000 units, and about 80 percent of the capacity uses CFCs (Fischer et al. 1991). The original replacement estimates had assumed a full 30-year service life on average. It is now anticipated that 20 years may be a more realistic average (Hayner 1993) as building owners weigh the costs and benefits of retrofitting existing chillers or changing them out altogether. The second row of projections assumes accelerated changeouts, and was used in this study. Domestic chiller shipments in 1993 (absorption, centrifugal, and rotary screw) were about 1.7 million tons, indicating that the CFC-driven upward trend in shipments is well under way.

\begin{tabular}{lccc} 
1000s of tons/year & $1996-2000$ & $2001-2005$ & $2006-2010$ \\
\hline Centrifugal/screw chillers & 1483 & 1398 & 1318 \\
Centrifugal/screw chillers (CFC replacement) & 2016 & 1889 & 1769 \\
\hline
\end{tabular}


It was assumed that essentially all of these electric chiller shipments could be contested by gas chillers. Chillers are used in large buildings in metropolitan areas, and almost all metro areas are served by gas. Although some large buildings do not have gas service, when heating, cooling, and other energy service needs are considered, the potential loads would justify modest line extensions in most cases.

\section{Gas Cooling Scenario Equipment Shipments Out to 2010}

Residential Unitary. A previous market assessment (Carlson 1994) was used to derive a relationship between projected gas heat pump shipments and selling price. The 334 metropolitan statistical areas (MSAs) were divided into 14 groups (or regions) based on climate, and MSAs in each region were further divided into 3 groups based on residential general service gas and electric retail rates. In each segment, the gas heat pump was compared with 18 conventional systems (all combinations of gas furnaces at two efficiency levels with air conditioners at three efficiency levels, in new-construction and replacement applications, i.e., $2 \times 3 \times 2=12$; and electric heat pumps at three efficiency levels, new and replacement, i.e., $3 \times 2=6$ ). In all, the national market was divided into 756 segments $(14 \times 3 \times 18)$.

The energy use, operating cost, and installed capital cost of the conventional system was determined for each segment. Gas heat pump incremental installed cost and operating cost established a simple payback for the challenging system in each segment. Gas heat pump market fraction was estimated for each segment using acceptance versus payback curves (unique for new construction and replacements). Market fractions were estimated by segment and then weighted by segment market size and aggregated for the nation. The process was repeated at several gas heat pump price points to generate a national market fraction versus price point curve. This curve provides a means of estimating annual market fraction at a given price point. Gas heat pump shipments over time were projected as described in the following paragraphs.

An engine-driven gas heat pump will be introduced in 1994 at a selling price of $\$ 5500$ for a 3-ton unit set in place (but not installed). Shipments during the 3-year introductory period are targeted below the potential shipments (national market fraction times national shipments of conventional units) and are essentially guaranteed as a result of a collaborative program involving the gas industry and the manufacturer. Thereafter, it is assumed that selling price drops by $10 \%$ in real terms every time shipment volume doubles (Boghosian 1993). An absorption gas heat pump will be introduced at $\$ 4500$ for a 3-ton unit in 1997 . The economics of absorption heat pump manufacturing require immediate large volumes, but the introductory price point makes this possible. A multiyear collaborative program should enable volumes to build quickly. The resulting shipment projections were made annually but aggregated to 5-year periods in the following table. 


\begin{tabular}{lccc} 
Unit/Yr & $1996-2000$ & $2001-2005$ & $2006-2010$ \\
\hline Total available market & $2,300,000$ & $2,501,000$ & $2,753,000$ \\
Gas heat pumps & 75,400 & 263,500 & 392,900 \\
\% of market gas cooling & $3.3 \%$ & $10.5 \%$ & $14.3 \%$ \\
\hline
\end{tabular}

These projections are based on 3-ton engine-driven units introduced in 1994 at $\$ 5500$, with price reductions to $\$ 4950$ in $1997, \$ 4455$ in 1998 , and $\$ 4009$ in 2000; and 3-ton absorption units introduced in 1997 at $\$ 4500$, with price reductions to $\$ 4050$ in $1998, \$ 3645$ in 2000 , and $\$ 3280$ in 2003. These pricing potentials are believed to be realistic by the manufacturers involved. Although the price points indicated are for 3-ton units (set in place, not installed), capacity increment product lines will be offered. Additional market penetration by gas-fired desiccant technologies may be possible in residential applications, but that potential was not considered here.

Commercial Unitary. A previous market assessment (Carlson 1994) was used to derive a relationship between projected gas heat pump rooftop shipments and selling price. A market segmentation procedure was used, similar to the residential analysis described earlier. In each market segment, the gas heat pump competed against 20 conventional systems (five efficiency levels - two each for G/Es and E/Es and one for EHPs, with and without air-side economizers, and new construction and replacement, i.e., $5 \times 2 \times 2=20$ ). In all, the national market was divided into 840 segments $(14 \times 3 \times 20)$.

The energy use, operating cost, and installed capital cost of the conventional system was determined for each segment. The incremental installed cost and operating cost of a gas heat pump rooftop unit established a simple payback for the challenging system in each segment. Market fraction was estimated for each segment using acceptance versus payback/cost premium curves. Market fractions were estimated by segment and then weighted by segment market size and aggregated for the nation. The process was repeated at several rooftop unit price points to generate a national market fraction versus price point curve. This curve provides a means of estimating annual market fraction at a given price point. Gas heat pump rooftop shipments over time were projected as described in the following paragraphs.

An engine-driven rooftop unit will be introduced in 1995 (a year after the residential unit) at a selling price of $\$ 1700 /$ ton for a 7.5-ton unit set on the roof curb and hooked up. A 7.5-ton absorption rooftop unit will be introduced at $\$ 1500 /$ ton in 1998 . Rooftop unit price drops are assumed to lag those of residential units by 1 year, leveraging off the component volume generated by the residential shipments. The resulting shipment projections were made annually but aggregated to 5year periods for presentation in the following table. 


\begin{tabular}{lccc} 
Unit/Yr & $1996-2000$ & $2001-2005$ & $2006-2010$ \\
\hline Total available market & 700,000 & 868,000 & $1,161,000$ \\
Gas heat pumps & 16,800 & 86,500 & 190,700 \\
\% of market gas cooling & $2.4 \%$ & $10 \%$ & $16.4 \%$ \\
\hline
\end{tabular}

These projections are based on 7.5-ton engine-driven units introduced in 1995 at $\$ 1700$ /ton, with price reductions to $\$ 1530 /$ ton in 1998 , $\$ 1377 /$ ton in 1999 , and $\$ 1239 /$ ton in 2001 ; and 7.5 -ton absorption units introduced in 1998 at $\$ 1500 /$ ton, with price reductions to $\$ 1350 /$ ton in 1999 , $\$ 1215 /$ ton in 2001 , and $\$ 1093 /$ ton in 2004 . These pricing potentials are believed to be realistic by the manufacturers involved. Although the price points indicated are for 7.5-ton units (set in place and hooked up), capacity increment product lines will be offered. Additional penetration by gasfired desiccant technologies, gas cooling-only rooftop units, or gas cooling/gas furnace rooftop units may be possible, but those options were not considered here.

Chillers. A previous market assessment (MacDonald, Hughes, and McLain 1992) was used to estimate the gas chiller market share achievable by 2010 . Thirty seven of the largest MSAs were divided into five groups (or regions) based on climate, and MSAs in each region were further divided into three groups based on large commercial general service gas and electric retail rates. In each segment, gas chillers competed against electric centrifugal chillers under eight different circumstances (dual fuel chiller plants where gas chillers provide $25 \%, 50 \%, 75 \%$, and $100 \%$ of the chiller capacity, new construction versus replacement, i.e., $4 \times 2=8$ ). It was assumed that end-users would select chiller plants with the highest gas chiller substitution levels meeting their payback criterion, which left two rather than eight circumstances requiring market segment assignments. In all, the national market was divided into 30 segments $(5 \times 3 \times 2=30)$.

The 30-segment analysis was repeated for two building types to bound the reasonable range of gas chiller national market share. A hospital was used as the high chiller load factor application, and an office building was used as the low chiller load factor application. Explained another way, gas chiller market share was estimated assuming all chillers go to hospitals and assuming all chillers go to offices, and the average of the two cases was used in this analysis.

The segment analysis was performed with the simple payback hurdle as a parameter ranging from 1 to 5 years. National market potential was estimated assuming that gas cooling captured all segments having paybacks less than the hurdle. Market potential associated with payback intervals (i.e., paybacks of 0-1 years, 1-2 years, etc.) was obtained by subtraction. Market acceptance in each payback interval was estimated by applying survey-derived acceptance criteria (Easton 1993).

It was assumed that the direct-fired double-effect absorption chiller cost premium of $\$ 200 /$ ton (full system installed) remained constant throughout the 15-year period, since both electric and doubleeffect absorption chillers are relatively mature products. Engine-driven and triple-effect absorption 
cost premiums were assumed to decline from $\$ 400 /$ ton to $\$ 350 /$ ton to $\$ 300 /$ ton in the three 5-year periods.

Direct-fired double-effect absorption chillers already are present in the market; therefore, it was necessary to distinguish between the reference case and the gas cooling scenario. For the reference case, it was assumed that the current $5 \%$ or so market share of direct-fired double-effect absorbers would continue through 2010, and that triple-effect and engine-driven units would never achieve significant shares. The four major domestic chiller manufacturers are all teamed with Japanese companies to share double-effect technology. Although many of the double-effect units come from Japan today, all domestic manufacturers have announced plans to make them in North America by 1996 (three in the United States, one in Mexico). Since even the Mexican plant uses U.S. materials, it was assumed that all reference case double-effect machines were made domestically from 1996 to 2010. The gas cooling scenario also assumes that all gas chillers (direct-fired double- and tripleeffect absorption, and engine-driven) shipped to domestic markets are made domestically.

\section{Reference Case}

\begin{tabular}{lccc}
1000 s of tons/year & $1996-2000$ & $2001-2005$ & $2006-2010$ \\
\hline Total available market & 2,016 & 1,889 & 1,769 \\
Direct-fired double-effect absorption chillers & 101 & 94 & 88 \\
\% of market gas cooling & $5 \%$ & $5 \%$ & $5 \%$ \\
\hline
\end{tabular}

\section{Gas Cooling Scenario}

\begin{tabular}{lccc}
1000 s of tons/year & $1996-2000$ & $2001-2005$ & $2006-2010$ \\
\hline Total available market & 2,016 & 1,889 & 1,769 \\
Gas chillers (all types) & 388 & 459 & 462 \\
$\%$ of market gas cooling & $19.2 \%$ & $24.3 \%$ & $26.1 \%$ \\
\hline
\end{tabular}

Other underlying assumptions and data are included in Appendix A, including:

- typical size and type of gas cooling units that would be installed,

- typical conventional electric cooling equipment displaced by gas cooling,

- costs relative to conventional systems, and

- life of gas cooling equipment.

The input-output analysis requires a breakout of where dollars go when an end-user purchases a gas cooling device rather than an electric cooling device. The important categories of costs are manufacturing costs (labor and materials), wholesalers costs (if any), retailers costs, and end-users costs (equipment and materials). Typical breakouts are provided for each market in Appendix A. 


\section{SUMMARY DESCRIPTION OF GAS COOLING SCENARIO}

This section summarizes the implications of the underlying gas cooling data and projections, in terms of the aggregate characteristics of the gas cooling scenario relative to the reference case.

\section{Gas Cooling Capacity Shipments}

Projected gas cooling capacity shipments to domestic markets are summarized for residential unitary, commercial unitary, and chiller equipment classes in Fig. 1. Figure 2 summarizes projected domestic and export gas chiller shipments.

As indicated in Fig. 1, domestically, only gas chiller shipments are expected to be significant by 1996. Domestic chiller shipments are expected to grow through about 1999 and then remain relatively flat over the remaining period. The economics of gas chillers are strongly driven by retail electric and gas rates for large commercial and institutional buildings, and shipments flatten out as the markets with favorable rates are captured. Another factor is that domestic chiller shipments in general are expected to crest and decline slightly during this period.

Figure 2 illustrates our projection that domestic gas chiller volumes should enable U.S. manufacturers to build a technological edge that can be exploited in export markets such as Latin America and Asia. Only Japanese and U.S. manufacturers have significant gas chiller production capacity. Although Japan was the first to perfect direct-fired double-effect absorption equipment, the United States is expected to open a significant lead in triple-effect absorption technology based on a strong base of intellectual property and international patent protection. The U.S. technology for applying large engines in gas-fired applications is also world-class. Chiller exports also leverage considerable exports of ancillary equipment (e.g., cooling towers, pumps, controls), but these added benefits are not considered in this study.

The key to success in the domestic unitary markets is to build sufficient shipment volumes in the favorable areas so that volume/experience effects enable equipment pricing to reach broader markets. The projection in Fig. 1 calls for residential unitary to lead market entry, but for greater capacity shipments and market share to be achieved in commercial unitary in the longer run. 
The projections indicate that domestic gas cooling unitary shipments leverage considerable exports, though modest compared with those generated by chillers. Whereas gas chillers in international airports, resorts, government buildings, and hospitals are large enough gas loads to help justify initial construction of gas infrastructure in developing countries, extensive gas grids reaching residential and commercial customers are needed to support unitary sales. The number of countries with such grids is expanding, but many of them have climates with little need for cooling in small buildings (Europe) or have closed markets (Japan).

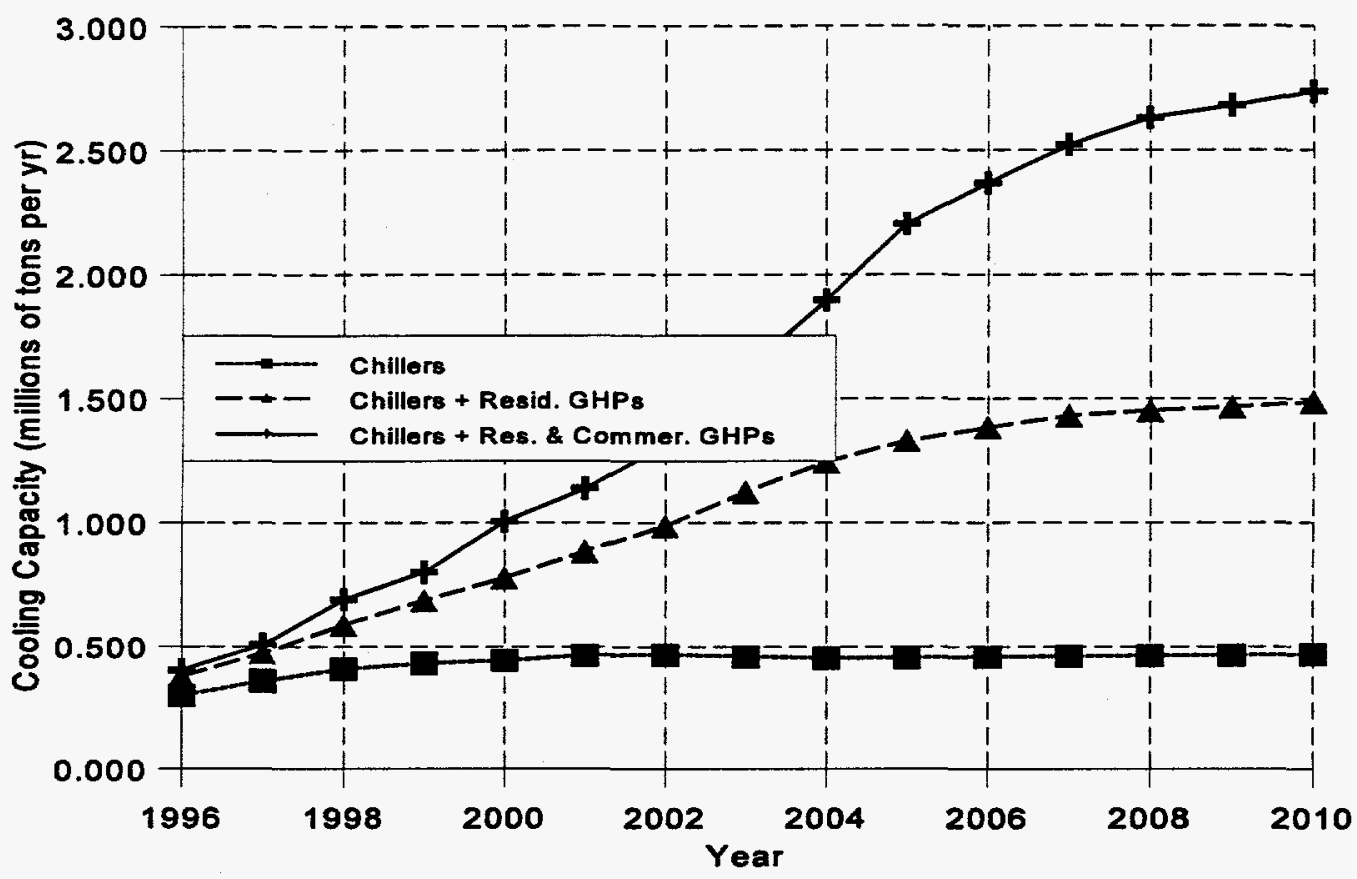

Fig. 1. Projected total domestic gas cooling capacity shipments. 


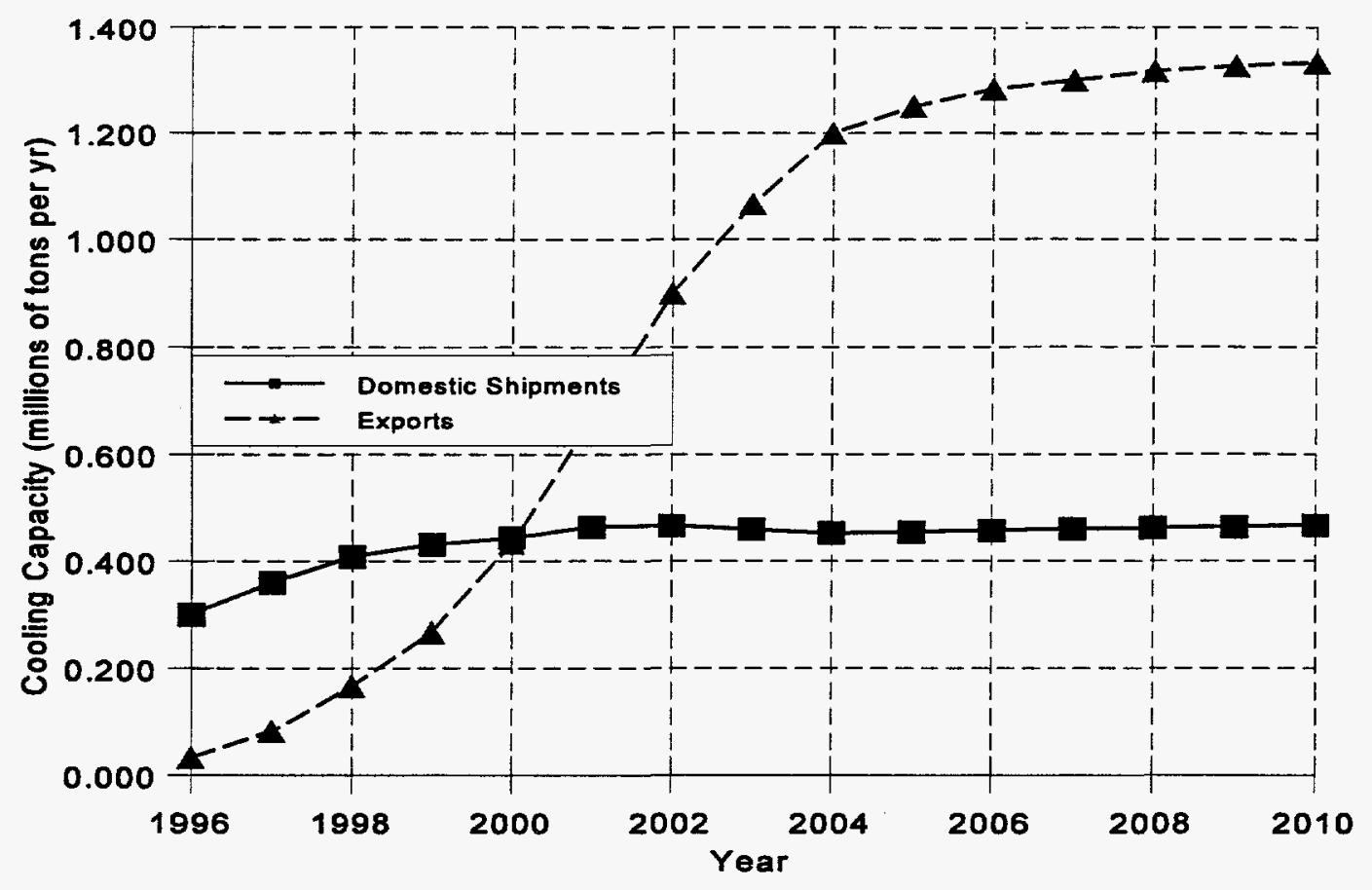

Fig. 2. Projected gas chiller capacity shipments

\section{Customer Bill Savings Attributable To Gas Cooling}

The three domestic market assessments kept track of customer bill savings based on actual retail gas and electricity rates as they existed in 1993. The by-year and cumulative results are presented in Fig. 3. It is estimated that by 2010 , customers will have saved about $\$ 17.6$ billion (1993 dollars) in utility bills as a result of gas cooling. Whether this projection is realistic depends on retail gas/electric price trends, which are difficult to predict.

The Energy Information Administration (EIA) projects flat electricity prices out to 2010 and rising gas prices, but these projections are averages across all customer classes (EIA 1993). Neither EIA nor anyone else has had much success in predicting the by-class retail price impacts of deregulation and the growth of competition in the utility industry. The gas industry experience since restructuring for the more competitive environment has been that large industrial and power generator customers have seen gas price decreases, and core customers (where most gas cooling equipment is used) have seen increases. As large electricity customers achieve open access to wholesale (and perhaps retail) electricity supplies, core customer electric rates also may rise even if average prices are flat.

Our sensitivity analysis indicates that gas cooling does better in an environment of rising core customer energy rates because it is the bill savings that must justify the cost premium of gas cooling 
equipment. If electricity prices are flat and gas prices rise, gas heat pumps do better against furnace/air conditioners. If the reverse is true, they do better against electric heat pumps. The straight fixed variable interstate pipeline rate design imposed by Federal Energy Regulatory Commission Order 636 likely will motivate seasonal retail pricing by gas distributors (higher in winter, lower in summer) that will benefit all classes of gas cooling equipment. As the electric industry deregulates and restructures, revenue requirements from core customers likely will rise because of low underlying load factors compared with large wholesale (and perhaps retail) users of electricity.

Increasingly, the retail rates of gas and electricity distributors will be driven by the load factors of the customer classes they serve. Since gas cooling improves the load factor of both gas and electricity core customers, retail rates may evolve in directions that favor gas cooling. Under the assumptions of the gas cooling scenario and based on a national calculation, the equivalent load factor of the electric load lost is $19.3 \%$ (sales lost divided by the product of summer generator capacity avoided and $8760 \mathrm{~h} /$ year) compared with a typical electric utility load factor of 50 to $60 \%$ averaged across all customer classes. The equivalent load factor of the gas load added is $127 \%$ (sales added divided by the product of winter peak day throughput increase and 365 days/year) compared with a typical gas distributor load factor of 30 to $40 \%$. The equivalent load factor of the gas load added exceeds $100 \%$ because chillers add nothing to winter peak day throughput and gas heat pumps displacing furnace/air conditioners and gas/electric rooftop units lower winter peak day throughput in most climates.

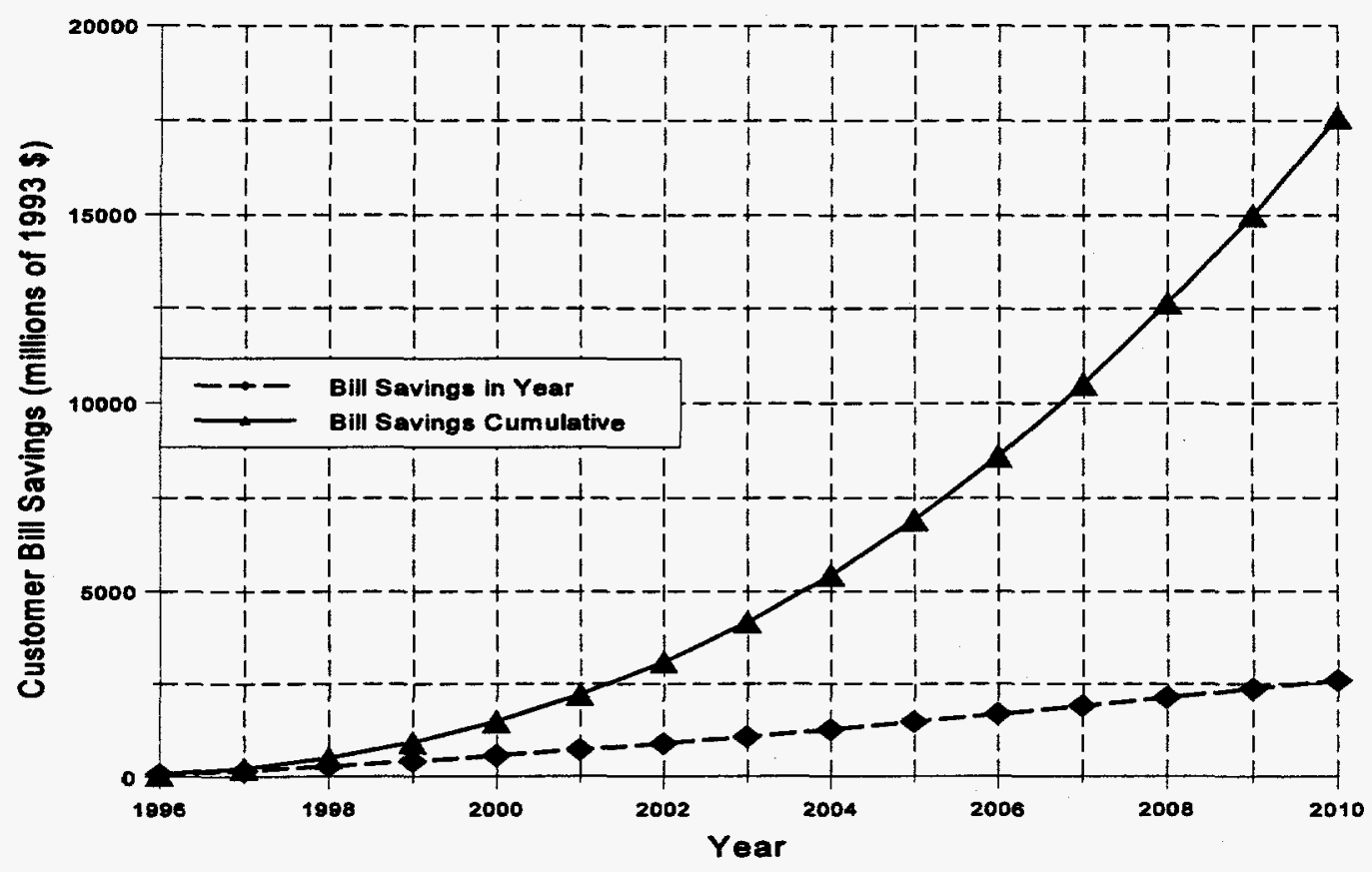

Fig. 3. Customer bill savings attributable to gas cooling. 


\section{Investment In Gas Cooling Equipment}

The three domestic market assessments kept track of the cost premiums paid by end-users to place gas cooling equipment into service rather than the displaced conventional equipment. Cumulatively over the 15-year period, about $\$ 3.3$ billion (1993 dollars) extra was spent by end-users in return for $\$ 17.6$ billion (1993 dollars) in bill savings.

\section{Customer Payback on Gas Cooling Investments}

The three domestic market assessments were based on customer acceptance criteria appropriate for the various markets. All three used simple payback (cost premium divided by annual bill savings) in some way. The customer acceptance at a given payback level varied by market segment and in the case of commercial unitary, simple payback and cost premium were used independently. The bottom line is that acceptance criteria were realistic and gas cooling investments occured when they made financial sense to end-users.

Figure 4 presents the global payback for all gas cooling investments made in each year. In the early years, shipments are concentrated in areas with favorable retail gas/electricity rates and climates. As time goes on, the cost premium of gas cooling is modest and acceptance occurs in many areas.

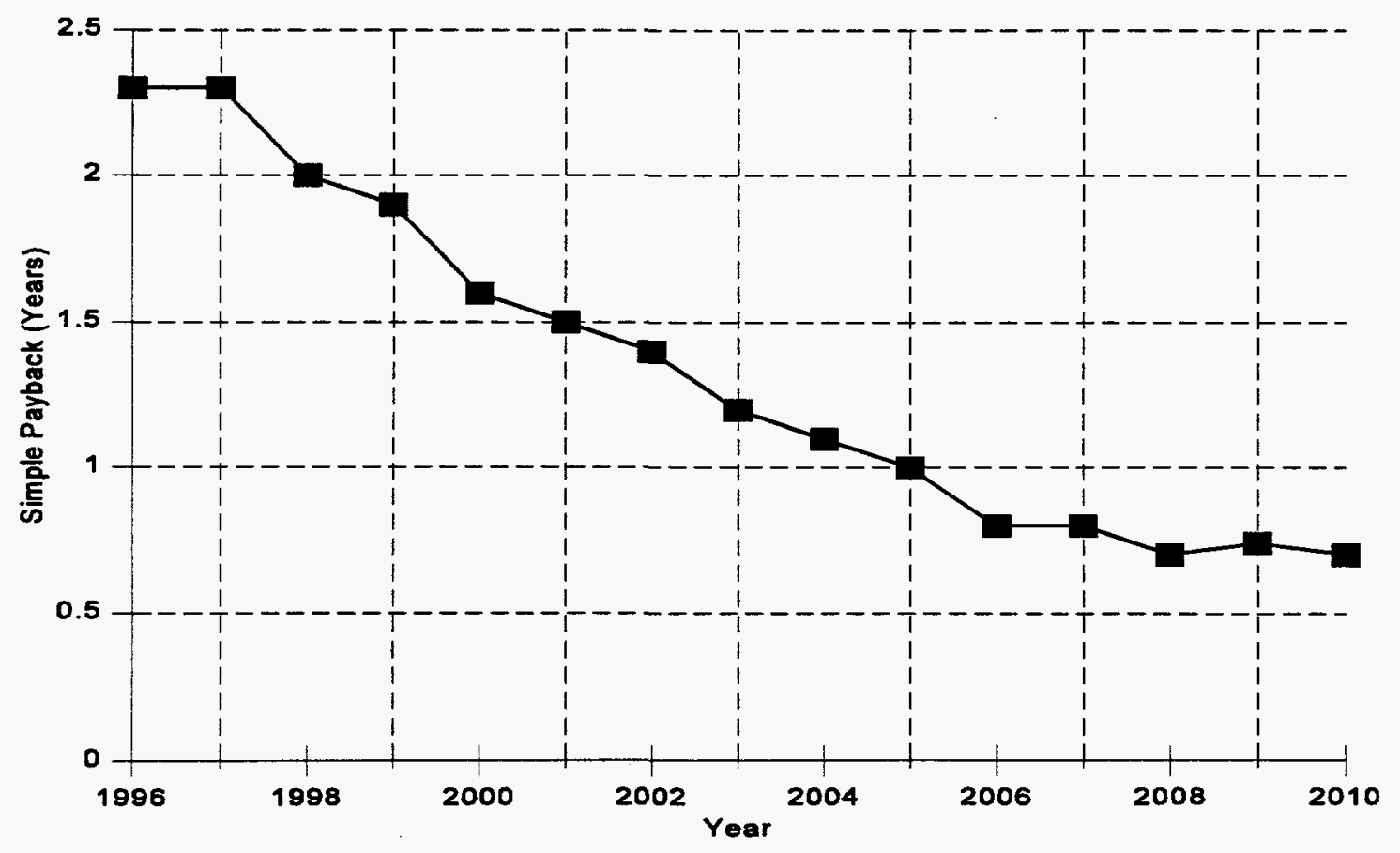

Fig. 4. Customer simple payback on gas cooling investments. 


\section{Potential Impact on Electric and Gas Utilities}

Over the 15 years, the gas cooling scenario would result in the additional use of 288.6 BCF of gas in core customer buildings, and would avoid the need for $33,410 \mathrm{GWh}$ of electricity at the power plant busbar (assuming transmission and distribution losses of $8 \%$ ). The domestic market assessment approaches also kept track of the location, equipment class, and efficiency level of the displaced conventional HVAC equipment. From this, the analyses derived summer peak kW/ton savings at the building meter. The coincidence between building cooling peak and utility system peak is defined by the coincidence factor. The electricity generating capacity avoided by gas cooling was estimated assuming coincidence factors of $0.8,1.0$, and 1.0 for residential unitary, commercial unitary, and chiller equipment, respectively; electricity transmission and distribution losses of $8 \%$; and electricity generation reserve margin requirements of $15 \%$.

The by-year and cumulative results are presented in Fig. 5. Under the assumptions of the gas cooling scenario, about $18.3 \mathrm{GW}$ of generating capacity would be avoided by the year 2010 . That represents almost $10 \%$ of the total generating capacity additions by 2010 in the EIA reference case (EIA 1993).

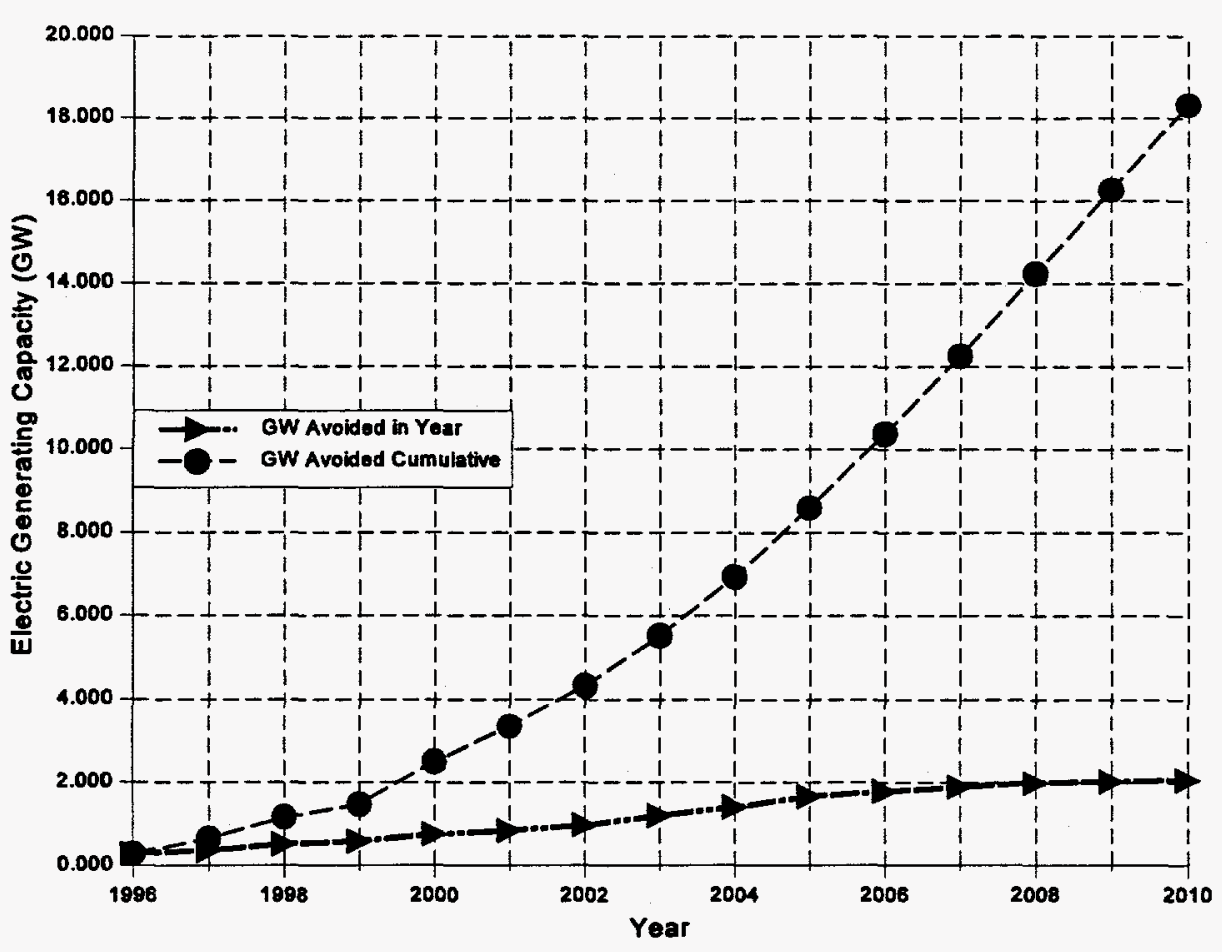

Fig. 5. Electricity generating capacity avoided by gas cooling. 


\section{EXPLAINING INPUT-OUTPUT ANALYSIS}

Energy efficiency strategies are options that are being explored more frequently by state and federal agencies as a means to sustain new domestic employment opportunities (Geller, DeCicco, and Laitner 1992; and Laitner 1994a). As cost-effective energy efficiency investments are pursued, economic efficiency is strengthened. One positive offshoot of such efficiency improvements is the strengthening of the local employment base. Input-output analysis is one tool that can assist in evaluating the job and income benefits resulting from different energy strategies. It is sometimes referred to as multiplier analysis.

\section{The Input-Output Concept}

An input-output model allows an analyst to examine the economic makeup of a regional economy, and then determine how a change in spending or investments might affect overall economic activity in the region. For example, in the energy sector, an input-output model can examine how much of the total revenues generated by utility customers are used to support local jobs and their associated payrolls. It can also evaluate how energy alternatives will increase or decrease the total regional employment base.

For the purposes of this study, input-output analysis can be thought of as a means to evaluate and sum the job and income benefits (output) likely to result from the changes in spending patterns (inputs) created by investments in gas cooling technologies.

To determine the total economic effects of any technology investment-for example, the installation of a gas cooling unit in a large commercial building - three separate effects must first be evaluated. These include the direct effect, which refers to the work done by a contractor or crew hired to do the installation; the indirect effect, which includes any operation necessary to support the work of the contractor (e.g., design professionals, wholesale suppliers, manufacturers, component suppliers); and the induced effect, which refers to other spending that results from the wages of those directly and indirectly employed by a project. This last category might include money for groceries, educational expenditures, recreational activities, or clothes.

To generate a complete impact analysis of an efficiency investment, two additional impacts must also be examined for their direct, indirect, and induced effects. These are the substitution and displacement effects. The substitution effect is the net savings (or loss) generated by the installation of the improvement. In effect, the investment is a means of substituting source energy efficiency, gas cooling technologies, and a lower-priced form of energy (natural gas) for source energy consumption, electric technologies, a higher-priced form of energy (electricity), and additional electric generation, transmission, and distribution facilities. A net savings would result in increased local spending equal to the energy bill savings. 
The displacement effect, on the other hand, is the loss of revenue to local electric utilities and electric equipment suppliers as a result of the efficiency improvements. All or part of the revenues might be an economic loss to the United States.

This study applies input-output analysis to evaluate the impact of expanding the use of gas cooling technologies within the United States and elsewhere. The approach is based on the following scenarios:

- A reference case that reflects current policies, practices, and trends with respect to conventional electrical cooling technologies; and

- A gas cooling scenario that examines the impact of accelerated use of natural gas cooling technologies.

The analytical framework used to estimate the full range of these impacts is the national data tables associated with the U.S. Department of Commerce Regional Input-Output Modeling System (RIMS II). This model contains information on 528 different sectors of the national economy. Since each sector of the economy supports a different level of wage and salary income or employment, as the level of expenditures increases or decreases, so do the income and employment levels.

The effect of the expenditure changes can then be represented by a total multiplier. For example, using the 1989 RIMS database (RIMS 1992) for the United States, electric utility services will support 18 total jobs for every million dollars of revenues collected from electric utility customers. This includes the direct, indirect, and induced employment that results from the investment. In this case, then, 18 is used as the employment multiplier for electric utility services. By way of comparison, manufacturing sectors have an employment multiplier that ranges from 21 to 41 jobs. Commercial sector multipliers range from 30 to 60 jobs. Furthermore, it is the manufacturing and commercial sectors, more than utilities, that can be expected to generate exports.

To summarize, then, each change in expenditures must be augmented by the multiplier that is appropriate for that sector. The sum of these products will then yield a net result. For example, if an investment in gas cooling technologies produces an energy bill savings, the lower net utility revenues may lead to a loss of jobs. But, to calculate the net employment benefits, it is necessary to adjust this apparent loss of employment by the number of jobs created or supported by energy bill savings which benefit other sectors of the economy. Thus an appropriately defined input-output analysis provides a full picture of the net total employment impacts sustained by technology changes.

The input-output analysis framework is constructed to estimate the net job and income benefits of domestic gas cooling shipments. But once established, the same framework provides a rational basis to estimate the net benefits of exports that displace products manufactured in other nations. 


\section{Constraints in the Model}

While the input-output model provides a useful tool in the analysis described above, it should be recognized that the data associated with RIMS (or any other such model) have limitations which can affect the results presented in this study. These are briefly reviewed below. Despite the inherent limitations, however, the scenarios as presented here either minimize the impact of the analytical drawbacks, or they depend on procedures which tend to offset those limitations.

Perhaps the most important weakness of input-output models is that they assume a linear relationship in their production functions. In other words, if final demand for a specific technology is doubled, total employment and/or income returns will also be doubled. In the case of gas cooling technologies this may be a conservative assumption which understates the net impacts on the economy. The reason is that an expanding market will bring about economies-of-scale and an increased learning curve that will tend to lower cost of production, and therefore alter the production function in a more positive way. By continuing with the assumption of a linear relationship, this benefit is not fully captured within the input-output model itself which likely understates both productivity benefits and the employment impacts.

Two other shortcomings are closely related to the linear assumption within the input-output framework. One is that the model is not supply constrained, and the other is that it does not capture the dynamic changes which might be spurred within the economy as the new gas cooling market emerges. As to the first, the survey undertaken for this analysis does not show any indication that the market will be unable to provide the necessary growth in raw materials, semi-finished products or skilled labor. Thus, correcting the analysis to account for supply constraints does not appear to be a necessary step.

In terms of a dynamic versus static analysis, the evidence also suggests that the static approximation will have a minimal impact at best. In the year 2010, for example, the incremental value of shipments for all gas cooling technologies shipped foreign and domestically is projected to be less than $\$ 800$ million (measured in constant 1993 dollars). This is less than 0.01 percent of the anticipated Gross Domestic Product for the U.S. in that year. Although a dynamic model could, for example, track how the higher investment drove up borrowing and, therefore interest rates, this is unlikely to be an important effect.

Another category of limitation deals with the change in capital stock brought about by the gas cooling scenario. In other words, the nation's productivity depends, in part, upon the extent and quality of manufacturing capital used to sustain the economic process. The problem is handled, in part, by treating the domestic shipments of gas cooling technologies as an investment which displaces conventional electric utility plant. To the extent that the shipments of electric cooling technologies are affected, the assumption is a one-to-one trade-off in capital investment.

Again, however, the relatively small scale of shipments (as a percent of GDP) implies an inconsequential impact. In fact, a Department of Energy analysis used to verify the results of 
Laitner's (1994a) study on the Climate Change Action Plan (Clinton, 1993) indicates that, if anything, the static model used here may understate the net employment benefits of efficiency investments relative to dynamic models (Laitner, 1994c).

\section{STEPS IN THE ANALYSIS}

\section{Establish a Reference Case}

The starting point or reference case in the analysis is the national data tables of the RIMS II database previously described. This database provides the information needed to describe the U.S. economy adequately so as to evaluate the economic changes brought about by variations in consumer and business expenditures. Thus the first step is to download the available national data and format them for use in a spreadsheet input-output model. Three issues should be noted at this point.

First, only selected sectors of the 528-sector national model are used. For example, the installation of the gas and electric cooling technologies can be reasonably described by three activities: the equipment production, the shipment and distribution, and the installation of the technology. This means, in turn, that we need to reference only three sectors representative of these activities. For the manufacturers, we selected Bureau of Economic Analysis (BEA) sectors 40.06 and 52.03 for the gas and electric technologies, respectively. For wholesale distribution, we selected BEA sector 69.01, and for installation, we selected special trade contractors found in BEA sector 12.01. Other key sectors include BEA 68.01 and 68.02 for the electric and gas utilities, respectively.

Second, the residential and commercial sectors used in this analysis are weighted averages rather than specific BEA sectors. For the residential sector, we weighted jobs and incomes based upon the typical spending patterns of households, using the personal consumption expenditure profile captured as BEA sector 91.00. For the commercial sector, we weighted BEA sectors 69.02 through 79.00 , using the total output of each sector as published by the Bureau of Labor Statistics (BLS 1992). While this weighting scheme will likely not match the precise pattern of those sectors that actually install the gas cooling technologies, the resulting multipliers are reasonably conservative and provide a useful indicator of employment and income impacts.

Third, the latest RIMS data available at the time of this study are for 1989. The Bureau of Economic Analysis is in the process of updating its model to reflect changes in a number of accounting conventions. However, the pattern among sectoral multipliers likely will change very little between 1989 and 1990, or even through 1994 for that matter, as a result of minor changes in accounting conventions. Moreover, the limitations of the 1989 database were minimized by the overall project design. For example, all dollar values were converted to 1989 constant dollars before being used in the analysis, and then results were converted back to 1993 constant dollars. Future employment impacts were also deflated by an annual productivity improvement rate of $1.5 \%$ through the year 2010. 


\section{Establish the Underlying Assumptions and Data}

The assumptions and data categories used for the analysis are as follows:

- reference case equipment shipments out to 2010 ,

- gas cooling scenario equipment shipments out to 2010 ,

- typical size and type of gas cooling units that will be installed,

- typical conventional electric cooling equipment that will be displaced,

- costs relative to conventional systems, and

- life of gas cooling equipment.

These assumptions and data are described in previous sections, or in Appendix A.

\section{Establish the Gas Cooling Scenario}

The underlying assumptions and data are used to construct the gas cooling scenario. The scenario consists of appropriate inputs to the input-output model based on the series of activities and transactions embodied in the underlying data. With this approach to building a scenario, an activity should be thought of as the efficiency upgrade within a single year. If the gas cooling scenario envisions a 15-year program of accelerating installations-say 1996 to 2010-there will then be 15 separate activities associated with cooling improvements, each with its associated transactions.

The transactions associated with each activity are best explained with an example. Assuming a gas cooling upgrade with a 15 -year life as the activity, there might be 32 transactions associated with the activity over time. The first transaction is the efficiency upgrade itself. This is essentially the premium spent to install gas cooling. The second transaction involves the transfer of investment funds from other uses in order to finance the upgrade. The next 15 transactions are associated with the annual energy bill savings projected over the 15-year measure life. Finally, the last 15 transactions involve the revenues gained or lost by the appropriate energy suppliers.

\section{Design Spreadsheet Input-Output Model}

The next step is to transfer the information into a menu-driven LOTUS ${ }^{\mathrm{TM}}$ spreadsheet model (Version 2.4) to allow easier data entry, analysis, and printing of results. The spreadsheet, in effect, becomes the working model based upon selected sectoral data from RIMS and the LOTUS ${ }^{\mathrm{TM}}$ macro programming language. The input is the changes in spending brought about by the gas cooling scenario. The output is the projected wage and salary income and employment impacts that resulted from efficient gas cooling.

\section{Perform Scenario Analysis}

With the reference case established by the RIMS database, the gas cooling scenario was run for each of three major market categories, described in the following sections: (1) residential unitary, (2) commercial unitary and chillers, and (3) export sales. The analysis yielded net income and 
employment benefits attributable to each of the three market categories compared with the reference case. (For a recent review of input-output scenarios and studies, as well as their findings, see Laitner 1994b.)

\section{INPUT-OUTPUT ANALYSIS RESULTS}

The scenario data described earlier can be adapted for use within an input-output model to estimate income and employment impacts. This was done by matching the different transactions expected to occur in each of the three market categories (residential unitary, commercial unitary and chillers, and exports) for the years 1996 through 2010. This section describes the specific multipliers assumed in the model, the basic framework of the analysis, and the resulting scenario impacts. Finally, it offers a brief discussion of the findings.

\section{Sectoral Multipliers}

The table below provides the job and income multipliers used to match each transaction (or change in expenditure pattern) brought about by the market penetration of the gas cooling technologies. To summarize, the job multipliers represent the direct, indirect, and induced effect for each million dollars spent within each of the identified sectors. The income multipliers (identified as wages and salaries) reflect the direct, indirect, and induced effect for each dollar spent within each of the listed sectors. The data are all adapted from the national level coefficients of the Department of Commerce RIMS-II model (RIMS 1992).

Table 1. Multipliers for key economic sectors (1989 constant dollar basis)

\begin{tabular}{lcc}
\hline \multicolumn{1}{c}{ Sector } & $\begin{array}{c}\text { Total jobs } \\
\text { (per million dollars) }\end{array}$ & $\begin{array}{c}\text { Wages and salaries } \\
\text { (total per dollar) }\end{array}$ \\
\hline Manufacturing-gas units & 41 & 1.02 \\
Manufacturing_electric units & 37 & 0.89 \\
Distribution & 34 & 0.86 \\
Installation & 47 & 1.05 \\
Electric utilities & 18 & 0.49 \\
Gas utilities & 12 & 0.33 \\
Commercial buildings & 44 & 0.93 \\
Residential buildings & 29 & 0.62 \\
\hline
\end{tabular}

Source: Adapted from U.S. Department of Commerce data (RIMS 1992) 


\section{Framework for Analysis}

A quick review of the multipliers table reveals an important point. Looking at the jobs column, the gas and electric utilities have the smallest employment multipliers, 12 and 18 jobs, respectively. If we compare these with the commercial and residential sector values of 44 and 29 jobs, respectively, we can conclude that lower energy bills mean dollar savings will likely be spent in sectors with a greater employment impact.

At this point, two major steps in the input/output analysis have been completed - setting up the initial expenditure patterns associated with each of the three market categories, and developing the initial set of multipliers. We can understand how these steps fit together within an analysis by setting up a simple example problem to solve.

Let us use the example of a purchase of a gas cooling technology in a commercial office building. In this case, we want to know what would be the net job benefit based upon the $\$ 1.0$ million incremental cost of the gas technology over a comparable electric unit. Let us assume that with the $\$ 1.0$ million investment, the gas bill will increase by $\$ 6.5$ million over a 15 -year period. Let us further assume that the electric bill will decrease by a total of $\$ 14.0$ million over that same period, for a net utility bill savings of $\$ 7.5$ million. Moreover, let us further assume that the drop in electricity consumption will lead to a modest rate increase such that all commercial electric customers will pay an additional $\$ 2.0$ million in that 15 -year period.

At this point, we need to match the proper change in spending - typically referred to as changes in final consumer demand - with the correct job multipliers found in the table above. In this example, there are eight such calculations to be made and summed. These are shown as follows:

1. Investment impact $=\$ 1.0_{\text {gas technology }} \times 41_{\text {manufacturer }}=41_{\text {job gain }}$

2. Revenue impact $=-\$ 1.0_{\text {revenue loss }} \times 44_{\text {commercial }}=-44_{\text {job loss }}$

3a. Gas utility impact $=\$ 6.5_{\text {gas bill }} \times 12_{\text {gas utility }}=78_{\text {job gain }}$

3b. Gas customer impact $=-\$ 6.5_{\text {gas bill }} \times 44_{\text {commercial }}=-286_{\text {job loss }}$

4a. Electric utility impact $=-\$ 14.0_{\text {electric bill }} \times 18_{\text {electric utility }}=-252_{\text {job loss }}$

4b. Electric rate impact $=\$ 2.0_{\text {electric bill }} \times 18_{\text {electric utility }}=36_{\text {job gain }}$

4 c. Electric rate impact $=-\$ 2.0_{\text {electric bill }} \times 44_{\text {commercial }}=-88_{\text {job loss }}$

4d. Electric customer impact $=\$ 14.0_{\text {electric bill }} \times 44_{\text {commercial }}=616_{\text {job gain }}$

5. Net impact $=101_{\text {net jobs in } 15 \text {-year period }}$ 
According to this example, total employment will be increased by 101 job-years compared with the employment generated by buying an electric cooling unit. Averaged over the 15-year period, the calculation means that the investment supports a net increase of about six or seven new jobs each year for the 15 years. This net benefit includes the direct, indirect, and induced effects of all expenditure flows. Similar calculations would be done for the wage and salary multipliers to generate estimates of net income benefits.

Some observers might note the great deal of volatility necessary to create a net gain of 101 job-years. Adding up the figures from the example above, we would show an employment gain of 771 jobyears. The majority of that impact occurs from the respending of energy bill savings in the commercial sector during the 15-year period of analysis. At the same time, the scenario shows a loss of 670 jobs - primarily associated with the higher gas costs for commercial customers and lost electric utility revenues.

Strictly speaking, however, these numbers represent the opportunity cost of employment rather than a loss of employment as such. In other words, the question might be asked whether the market chooses a scenario that will increase employment by 771 jobs, or one that generates only 670 jobs. As we shall see, as the cumulative global investment in gas cooling technologies begins to climb up toward the $\$ 9.0$ billion mark (1993 constant dollars, as shown in Tables 2,3 , and 4, below), this can have an important impact.

Before we can estimate the final impacts of the three market categories, we must make a number of adjustments in the expenditure patterns described above. First, all expenditures must be converted to 1989 dollars to properly match the base-year of the RIMS model (results are then converted back to 1993 constant dollars for presentation in Tables 2, 3, and 4). Second, all labor estimates in the years 1996 through 2010 must be adjusted downward to reflect productivity improvements. For the purposes of this analysis, it was assumed that labor productivity will increase by an average of 1.5 percent per year. This is higher than the 1.0 percent average over the last decade, but the effect will be to slightly understate net employment benefits.

Third, it is assumed that about 30 percent of electricity bill savings represent fixed costs that will need to be spread out among all commercial and residential customers. In effect, the assumption is that electric rates will increase slightly as a result of the gas cooling scenario. But the effect is modest, raising rates by less than 0.01 percent. Since the level of fixed costs will diminish over time, and since the analysis did not provide a corresponding positive impact on natural gas retail rates, this result is a conservative estimate of net employment effects.

Finally, no parameters are established to account for changes either in interest rates or in labor participation rates as a result of the analysis. These impacts are expected to be minimal, however. While the higher premiums associated with the gas technology might be expected to drive up borrowing and, therefore interest rates, this effect will be offset by a greater savings in the avoided cost of new power plant capacity. Similarly, while an increase in demand for labor tends to increase the overall level of wages (and thus tends to lessen economic activity), the gas cooling scenario job 
benefits, though significant, are still small compared to the current total national level of unemployment or underemployment.

The substitution and displacement adjustments apply only to the domestic residential and commercial market categories. In the export category, it is assumed that the increased shipments of gas cooling technologies would not displace the export of electric cooling technologies manufactured domestically, but rather would displace products manufactured by other nations. Neither would international exports affect domestic energy consumption by residential and commercial customers. As a result, the value of shipments (in 1989 dollars) is simply matched to the manufacturing and wholesale multipliers to derive the net job and income benefits for the United States.

\section{Market Category Impacts}

The following tables summarize the net impact of the three gas cooling marketing categories: (1) residential, (2) commercial unitary and chillers, and (3) exports. The values provided are average annual values for each of three periods: 1996-2000, 2001-2005, and 2006-2010. The cumulative impacts are also provided, as are the impacts in 2010.

As might be expected, the residential market category shows the smallest 15 -year net benefit of 103,460 job-years. The reasons are two-fold. First, the overall investment is smaller, with a premium of $\$ 987$ million compared with $\$ 2,322$ million for the commercial scenario and $\$ 5,714$ million for the export scenario (all in 1993 dollars). Second, the difference between the household multiplier and the utility multipliers is much smaller than the difference between the commercial and the utility multipliers. Finally, since the export scenario does not compete either with electric technologies or with electric energy consumption, there are no losses to subtract from the increased export activity. That, coupled with over five billion total sales, generates the second largest cumulative increase in job benefits, showing a 15-year total employment increase of 155,320 jobyears. The commercial category generates the largest employment increase of 367,242 job-years because of a large investment level coupled with a large difference between the commercial and utility multipliers. 
Table 2. Summary impacts from domestic residential gas cooling shipments

\begin{tabular}{|c|c|c|c|c|c|}
\hline & \multicolumn{3}{|c|}{ Average annual impacts } & \multirow{2}{*}{$\begin{array}{c}\text { 15-year } \\
\text { total }\end{array}$} & \multirow{2}{*}{$\begin{array}{l}\text { Impact } \\
\text { in } 2010\end{array}$} \\
\hline & $1996-2000$ & 2001-2005 & $2006-2010$ & & \\
\hline Actual units shipped & 75,406 & 263,492 & 392,900 & $3,658,988$ & 407,683 \\
\hline Investment premium (\$MM) & 76.4 & 70.9 & 50.1 & 987.3 & 48.7 \\
\hline Natural gas bill (\$MM) & 63.6 & 232.8 & 418.0 & 3572.1 & 492.2 \\
\hline Electricity savings (\$MM) & 177.1 & 685.4 & 1330.0 & 10962.4 & 1597.6 \\
\hline Net income (\$MM) & 30.3 & 27.2 & 48.9 & 532.2 & 73.2 \\
\hline Net employment (jobs) & 1,371 & 5,089 & 14,232 & 103,460 & 19,405 \\
\hline
\end{tabular}

Note: All values are in millions of 1993 dollars, except shipments and jobs, which are in actual units.

Table 3. Summary impacts from domestic commercial gas cooling shipments

\begin{tabular}{|c|c|c|c|c|c|}
\hline & \multicolumn{3}{|c|}{ Average annual impacts } & \multirow{2}{*}{$\begin{array}{c}\text { 15-year } \\
\text { total }\end{array}$} & \multirow{2}{*}{$\begin{array}{l}\text { Impact } \\
\text { in } 2010\end{array}$} \\
\hline & $1996-2000$ & 2001-2005 & $2006-2010$ & & \\
\hline Actual units shipped (tons) & 488,955 & 978,515 & $1,605,825$ & $15,366,473$ & $1,717,628$ \\
\hline Investment premium (\$MM) & 144.5 & 169.4 & 150.5 & 2322.0 & 146.7 \\
\hline Natural gas bill (\$MM) & 74.9 & 324.6 & 735.9 & 5677.0 & 925.0 \\
\hline Electricity savings (\$MM) & 258.0 & 957.6 & 1958.9 & $15,872.9$ & $2,402.3$ \\
\hline Net income (\$MM) & 87.5 & 456.7 & 1150.9 & $8,475.1$ & $1,492.4$ \\
\hline Net employment (jobs) & 3,182 & 19,830 & 50,437 & 367,242 & 65,347 \\
\hline
\end{tabular}

Note: All values are in millions of 1993 dollars, except shipments and jobs, which are in actual units. 
Table 4. Summary impacts from gas cooling exports

\begin{tabular}{lccccc}
\hline & \multicolumn{4}{c}{ Average annual impacts } & 15-year \\
\cline { 2 - 5 } & $\mathbf{1 9 9 6 - 2 0 0 0}$ & $\mathbf{2 0 0 1 - 2 0 0 5}$ & $\mathbf{2 0 0 6 - 2 0 1 0}$ & $\begin{array}{c}\text { Impact } \\
\text { in 2010 }\end{array}$ \\
\hline Shipments (\$MM) & 99.2 & 454.6 & 589.0 & $5,713.8$ & 599.6 \\
Net income (\$MM) & 98.5 & 451.5 & 585.1 & 5675.5 & 595.6 \\
Net employment (Jobs) & 2,966 & 12,727 & 15,371 & 155,320 & 15,189 \\
\hline
\end{tabular}

Note: All values are in millions of 1993 dollars, except jobs, which is in actual units.

\section{CONCLUSIONS}

We estimate that the gas cooling scenario (domestic residential, domestic commercial, and exports) would create a net of 626,000 job-years of new employment in the period from 1996 through 2010 . In this 15 -year period, this would be an average employment gain of 41,700 jobs. The employment gain in the year 2010 would be about 100,000 jobs. We also estimate that the gas cooling scenario would create $\$ 14.7$ billion in new wage and salary income through 2010 , an average of $\$ 979$ million annually (1993 dollars). The wage and salary gain in the year 2010 is $\$ 2.2$ billion (1993 dollars).

In addition to the income and employment benefits, the gas cooling scenario would generate about $\$ 5.7$ billion (1993 dollars) in cumulative net exports through 2010. The scenario would avoid 18.3 GW of new electric power generation by the end of 2010 and save domestic residential and commercial customers $\$ 17.6$ billion (1993 dollars) in utility bills through 2010 . Finally, the scenario would expand domestic HVAC markets by $\$ 3.3$ billion (1993 dollars) through 2010 (this is in addition to the $\$ 5.7$ billion increase in HVAC exports).

The gas cooling scenario would expand the efficient use of natural gas. Over the 15 years, an additional 288.6 BCF of natural gas would be consumed in residential and commercial buildings and the use of $33,410 \mathrm{GWh}$ of electricity (at the power plant busbar) would be avoided. The exact resource energy savings are difficult to establish because of the wide regional and temporal variations in energy use associated with electric power generation. Nonetheless, at an electric generation heat rate of $11,400 \mathrm{Btu} / \mathrm{kWh}$ the primary energy savings would be about 0.09 quads per year by 2010 . 


\section{REFERENCES}

ADL 1993. "Briefing on International Markets for Gas Heat Pumps." Prepared by Arthur D. Little for John Ryan of Department of Energy. U.S. Department of Energy, Washington, D. C.

AGA 1991. 1992 Gas Facts-1991 Data: A Statistical Record of the Gas Industry. Table Series 13. American Gas Association, Arlington, Va.

ARI 1994. "Statistical Profile of the Air-Conditioning, Refrigeration, and Heating Industry." AirConditioning and Refrigeration Institute, Arlington, Va.

ASHRAE 1987. HVAC Systems and Applications Handbook, p 49.7.

BLS 1992. Industry Output and Employment Historical Data. Office of Employment Projections, Bureau of Labor Statistics, U.S. Department of Labor, Washington, D. C.

Boghosian 1993. Personal communication between S. Boghosian of Lawrence Berkeley Laboratory and Patrick Hughes of Oak Ridge National Laboratory.

Carlson, S., B. Duffy, C. Flynn, H. Henderson, and P. Hughes 1994. Gas Heat Pump Market Assessment: Summary Report, ORNL/Sub-93-62B-99179C/1, The Fleming Group for Department of Energy via Oak Ridge National Laboratory, January. (In publication).

Clinton, W. J. et al., 1993. The Climate Change Action Plan. Executive Office of the President, Washington, DC, October.

Commerce 1994. Personal communication between Ms. Roundtree of the Department of Commerce Census Bureau and P. J. Hughes of Oak Ridge National Laboratory.

DeLima Associates 1992. HVAC Market Assessment: Presentation Exhibits, for Gas Research Institute under contract 5090-245-1955, December 16.

Easton Consultants Inc. 1993. Natural Gas Cooling Market Study: Executive Summary, Final Report Part 1, Final Report Part 2, for the American Gas Association and the American Gas Cooling Center, February.

EIA 1991. Annual Outlook for Electric Power. Table 7, p. 20, DOE/EIA-0474(91). Energy Information Administration/U. S. Department of Energy, Washington, D. C., July.

EIA 1992. Housing Characteristics 1990. Table 19, DOE/EIA-0314(90), Energy Information Administration/U. S. Department of Energy, Washington, D. C. , May. 
EIA 1993. Annual Energy Outlook 1993-With Projections to 2010. Table A3. DOE/EIA0383(93), Energy Information Administration/U. S. Department of Energy, Washington, D. C. January.

Energy International Inc., 1992. Assessment of Gas and Electric Cooling Equipment. TR-101142, Electric Power Research Institute, August.

Fischer, S. K., et. al. 1991, Energy and Global Warming Impacts of CFC Alternative Technologies, for the Alternative Fluorocarbons Environmental Acceptability Study and the U. S. Department of Energy, December.

Gas Utility Report, September 2, 1994. "Industry Groups Paint Rosy Picture for Future of GasCooling Equipment," P. 11, McGraw-Hill Inc., New York, NY.

Geletka, M. A. and J. T. Cobb 1993. Determination of Current and Potential Export Market of Natural Gas-Powered Cooling Equipment to Less Developed Countries. Energy Resources Program-University of Pittsburgh, for Consolidated Natural Gas Company and AGCC. American Gas Cooling Center, Washington, D. C. December.

Geller, H.; J. DeCicco; and S. Laitner 1992. Energy Efficiency and Job Creation: The Employment and Income Benefits from Investing in Energy Conserving Technologies. American Council for an Energy-Efficient Economy, Washington, D. C.

Hayner, A. M. 1993. Chiller Retrofit: Pay Now Or Pay Later. Engineered Systems, September.

Ives, G. 1993. "Outside U.S./Canada Report." Pipe Line Industry. Vol. 76 (11), 21, November.

Kaul, J. and S. Kihm 1992. Fuel Switching: Why it Should Be Done, Why it Isn't Done, and Ways Regulators can Address it. P. 473 in Proceedings of the Fourth National IRP Conference, National Association of Regulatory Utility Commissioners Washington, D. C.

Laitner, S. 1994a. The Climate Change Action Plan as an Economic Development Strategy for the United States. American Council for an Energy-Efficiency Economy, Washington, DC, May.

Laitner, S., I. Goodman, and B. Krier, 1994b. "DSM as an Economic Development Strategy." The Electricity Journal, Vol. 7(4), May, pp. 62-69.

Laitner, S., 1994c. "Jobs Study Misunderstood," Letters to the Editor, The Electricity Journal, Vol 7(8), September, pp. 2-3.

Lenssen, N. 1993. "A New Energy Path For The Third World." Technology Review, p. 43-51. October. 
Lewis, J. E, and A. Clarke 1990a. Replacement Market for Residential Energy Service Equipment. GRI-89/0204.02, Easton Consultants Inc. for Gas Research Institute, June.

Lewis, J .E, and A. Clarke 1990b. Replacement Market for Selected Commercial Energy Service Equipment. GRI-89/0204.01, Easton Consultants Inc. for Gas Research Institute, June.

MacDonald, J. M., P. J. Hughes, and H. A. McLain 1992. "Market Potential Estimates and R\&D Planning for Advanced Absorption Systems for Large Commercial Buildings," ASHRAE Transactions 98(2), 156-64.

NES 1991/92. National Energy Strategy Technical Annex 2-Integrated Analysis Supporting The National Energy Strategy: Methodology, Assumptions and Results. DOE/S-0086P, DE91 014058, Table A-19, p. 92, U.S. Department of Energy, Washington, D. C.

RIMS 1992. Regional Multipliers: A User Handbook for the Regional Input-Output Modeling System. 2nd Ed. Economics and Statistics Administration and the Bureau of Economic Analysis, U.S. Department of Commerce. Washington, D. C. May.

Solomon, C. and R. Johnson 1994. "Piping Up: Natural Gas Industry Is Reinventing Itself by Going International," Wall Street Journal, April 19.

Ueda, K. 1993. "Greater Role of Natural Gas in Cooling and Heating: Contribution to Environmental and Energy Conservation." in Proceedings of the IEA International Conference for Natural Gas Technology: Energy Security, Environment, and Economic Development. Kyoto International Conference Hall, Kyoto, Japan, October 31 to November 3. (In publication). 


\title{
APPENDIX A: SUPPLEMENTAL ASSUMPTIONS AND DATA
}

\author{
Typical Size and Type of Gas Cooling Units That Will Be Installed
}

\section{Residential Unitary}

Currently about $60 \%$ of conventional air conditioner and heat pump unit shipments are in the 2- to 3- ton range, with 3-ton units slightly outpacing 2- and 2.5- ton sizes (DeLima 1992). Of the remaining shipments, more are larger than 3-ton than smaller than 2-ton. The market analysis was forward looking in terms of residential heating and cooling loads for new homes and weatherized existing homes, and consequently projected that equipment sizes would trend downward. According to the analysis, gas heat pumps placed in 1996 had an average size of 2.6 tons. If manufacturers target large homes, the projected capacity shipments used here may be conservative.

Engine-driven gas heat pump. Commercial introduction of U.S.-manufactured engine-driven gas heat pumps to the U.S. market will occur in mid 1994. These units feature variable-speed internal combustion engines to drive the compressor of a conventional vapor compression cycle. The engine/compressor module is in the outdoor unit. The indoor blower is also variable-speed, and the outdoor fan is 2 -speed.

This product introduction marks the first direct use of natural gas where the delivered energy (heated space) exceeds the heat content of the gas consumed to produce it. The split system has four pipes between the indoor and outdoor units, two for the heat pump refrigerant and two for the anti-freeze loop. In heating mode, the anti-freeze loop recovers heat off the engine by means of an exhaust gas heat exchanger and by serving as the engine coolant.

An advantage of this unit over same-cooling-capacity electric air-source heat pumps is that heating capacity will be greater by the amount added by the heat recovery loop. A second advantage is that supplemental heat is provided by gas, which is lower in cost and more efficient than the electric resistance heat that backs up electric heat pumps. These two characteristics lead to engine-driven equipment selections based on cooling load, even in northern climates.

Absorption gas heat pump. Commercial introduction of U.S.-manufactured absorption gas heat pumps will likely occur in 1997. A variety of absorption concepts exist, but technology based on the GAX (Generator-Absorber-heat eXchange) absorption refrigeration cycle has been licensed by a major manufacturer, and a national team (including the manufacturer, the U.S. Department of Energy, the American Gas Cooling Center, and the Gas Research Institute) has formed to bring the technology to commercial introduction.

Absorption machines operate on a completely different principle from conventional vapor compression machines, so a few words of explanation are offered. The GAX heat pump is an adaptation of the simple absorption cycle, in which an absorber, a solution pump and a generator replace the function of the vapor compression cycle's compressor. After leaving the evaporator, the gaseous refrigerant (in this case ammonia) is absorbed into a water solution in the low-pressure 
absorber before being pumped to a high pressure by a solution pump. The solution then enters the generator, where heat from gas combustion is applied and the ammonia boils out of solution. Then the high-temperature and high-pressure ammonia is ready to go into the condenser, where it gives off its heat and condenses back into a liquid. After expanding to a lower pressure by moving through an expansion valve, the liquid ammonia is ready to pick up heat in the evaporator again, thereby completing the cycle.

The proximity of components in a simple absorption cycle creates several opportunities for using internally recovered heat to increase the ammonia refrigerant flow per unit of gas consumption. The GAX cycle improves on the simple absorption cycle by implementing several of these internal heat recovery opportunities.

The split-system configuration employs a secondary heat transfer fluid (HTF) to transfer heat between the outdoor unit and the indoor unit. This allows a compact absorption module containing the GAX cycle and the gas combustion subsystem to be located entirely in the outdoor unit. A valve controlling the HTF flow serves as the mechanism for switching between heating and cooling mode, without affecting the absorption module's flow.

An advantage of absorption heat pumps is that they are burner-based (i.e., continuous combustion when on), and capable of extremely low air pollutant emissions. A second advantage is price; at sufficient unit shipment volumes, only modest price premiums over standard gas furnace/airconditioner combinations may be possible. A third advantage of absorption units (compared with any vapor compression system) is that they avoid the use of ozone-depleting refrigerants.

\section{Commercial Unitary}

Commercial unitary shipments divide between the high-volume smaller units with standard sizes ranging up to about 25 tons, and larger custom units that often are "build-to-order" and may be 200 tons or more. This study focuses on the smaller units in which component costs can benefit from economies of scale created by piece volumes going to residential equipment. In this market, the shipment-weighted average unit size is about 7.5 tons. The same engine-drive and absorption technologies described earlier are embedded in package configurations appropriate for the light commercial market.

\section{Chillers}

Water-cooled packaged chillers range in size from 100 to 10,000 tons, but the very large chillers generally use HCFC-22 rather than CFCs and are few in number. Also, as older chiller plants are upgraded, there is a trend toward the use of several smaller chillers rather than one large one. The drivers of this trend are service convenience, reliability, and the economics of using a mix of gas and electric chillers. Consequently, the size range of interest in this study is more like 60 to 1,500 tons, and a typical size is about 200 to 500 tons.

The primary gas-fired chiller technologies are absorption and engine-driven. Absorption chillers can be single-, double-, or triple-effect and directly fired with gas (double- or triple-effect) or indirectly 
fired with steam (single- or double-effect). The more "effects" (i.e., levels of cascaded internal heat recovery) the higher the efficiency, but also the higher the required firing temperatures. Steam-fired units are used in applications where waste steam or district steam (15 psig can drive single-effect; $120 \mathrm{psig}$ can drive double-effect) are available. In some cases, the waste steam may be from enginedriven (or steam turbine-driven) chillers. This study focuses on direct-fired equipment, whether absorption or engine-driven.

Direct-fired absorption chillers use water (refrigerant) and lithium bromide (absorbent) as the fluid pair, except for some versions of the triple-effect that use advanced fluids in the high-temperature loop. Lithium bromide/water is also the basis for steam-driven absorbers, and such machines have been widely used since the 1950 s. Direct-fired double-effect absorption chillers are also available in a convenient chiller/heater configuration where both chilled and heated water are produced independently on demand. This configuration avoids the need for a separate boiler in central plants that serve four-pipe distribution systems, and may also be an option with triple-effect chillers in the future.

Engine-driven chillers are based on automotive or industrial engines modified for use with natural gas. The engine replaces the electric motor of a conventional chiller, driving the compressor. Opendrive compressors (i.e., the driver, in this case the engine, is not cooled by refrigerant) are used, but a variety of types are possible (reciprocating, rotary screw, centrifugal). Waste heat is available from the engine jacket and gaseous exhaust, if the application has a use for it.

\section{Typical Conventional Electric Cooling Equipment Displaced By Gas Cooling}

\section{Residential Unitary}

The market assessment methodology (Carlson 1994) keeps track of the conventional equipment displaced by gas heat pumps. At high price points, primarily electric heat pumps are displaced; but at lower price points, primarily furnace/air conditioner combinations are displaced. Over the 15 -year period about $70 \%$ of the conventional units displaced were furnace/air conditioners. Generally the displacements occur in extreme climates with high energy rates first, and then diffuse into areas with milder climates and lower energy rates as the price point declines. Higher efficiency electric heat pumps and furnace/air conditioners are often the first to be displaced because the cost premiums of gas heat pumps relative to these units are less, yet they offer significant bill savings.

\section{Commercial Unitary}

As with residential, the commercial unitary market assessment methodology (Carlson 1994) keeps track of the conventional equipment displaced by gas heat pumps. At high price points primarily $\mathrm{EHP}$ and $\mathrm{E} / \mathrm{E}$ rooftop units are displaced; but at lower price points, primarily $\mathrm{G} / \mathrm{E}$ rooftop units are displaced. Over the 15 -year period about $51 \%$ of the units displaced were G/Es, $35 \%$ were EHPs, and $14 \%$ were E/Es. Relative to the residential case, displacements were driven more by energy rates than climate. 


\section{Chillers}

The vast majority of electric chillers displaced are expected to be centrifugal machines, because they dominate the capacity shipments in chiller class equipment, and because they are most reliant on CFCs (and therefore vulnerable to early retirement). Rotary screw electric chillers are the next most likely to be displaced. Since the costs and efficiencies of these two types of electric chillers are similar, distinguishing between the two was not felt to be necessary. The chiller case does, however, have a number of different gas cooling options. Over the 15-year period about $32 \%$ of the gas cooling capacity shipped was double-effect absorption, $50 \%$ triple-effect absorption, and $18 \%$ engine-driven.

\section{Costs Relative to Conventional Systems}

The input-output analysis requires a breakout of where the dollars go when an end-user purchases a gas cooling device rather than an electric cooling device. The important categories of cost are manufacturing cost (labor and materials), wholesalers cost (if any), retailers cost, and end-users cost (equipment and materials). Typical breakouts are provided in this section for each market.

\section{Residential Unitary}

Although both engine-driven and absorption heat pumps are considered, their performance is similar enough (and different enough from conventional equipment) that distinguishing between the two was not felt to be necessary. Their differing introductory costs were only used to establish realistic price points by year; thereafter, total gas heat pump shipments per year were estimated. At a given price point, the cost of either type of gas heat pump system would break down about the same way, so one set of representative numbers was used.

The representative gas heat pump cost breakout is provided at the $\$ 4050$ price point, which corresponds approximately to the engine-driven unit after three price drops (year 2000) or the absorption unit after one price drop (year 1998). The bottom line cost shown is for equipment installed. The end-user's total project cost would be larger if a duct system needed to be installed (new construction) or significantly modified (replacement), but these extra costs would be required whether a gas heat pump was selected or not because the air moving requirements are essentially the same as for conventional equipment. 
Residential gas heat pump cost breakout

\begin{tabular}{|c|c|c|c|}
\hline & & $\$ / 3$-ton & $\%$ of bottom line \\
\hline Manufacturer cost: & equipment cost & 2268 & $46 \%$ \\
\hline \multirow[t]{3}{*}{ Distributor cost: } & equipment cost & 2268 & $46 \%$ \\
\hline & $20 \%$ gross margin & 567 & $12 \%$ \\
\hline & Total equipment & 2835 & $58 \%$ \\
\hline \multirow[t]{5}{*}{ Dealer/installation cost: } & equipment cost & 2835 & $58 \%$ \\
\hline & $30 \%$ gross margin & 1215 & $25 \%$ \\
\hline & Total equipment & 4050 & $83 \%$ \\
\hline & Installation & 850 & $17 \%$ \\
\hline & Equipment installed & 4900 & $100 \%$ \\
\hline End-user cost: & equipment installed & 4900 & $100 \%$ \\
\hline
\end{tabular}

Although gas heat pumps displace furnace/air conditioners and electric heat pumps at a variety of efficiency levels and in new and replacement applications, the cost breakout for displaced systems is primarily a function of the class of equipment. Therefore, one representative cost breakout for each equipment class displaced was used.

A common furnace/air-conditioner combination displaced by the gas heat pump was a condensing furnace ( 90 AFUE) with mid-efficiency air-conditioner (12 SEER) in a replacement application. The cost breakout for this system is as follows.

Condensing furnace with mid-efficiency air conditioner

\begin{tabular}{|c|c|c|c|}
\hline & & $\$ / 3$-ton* & $\%$ of bottom line \\
\hline Manufacturer cost: & equipment cost & 1882 & $45 \%$ \\
\hline \multirow[t]{3}{*}{ Distributor cost: } & equipment cost & 1882 & $45 \%$ \\
\hline & $20 \%$ gross margin & 470 & $11 \%$ \\
\hline & total equipment & 2352 & $56 \%$ \\
\hline \multirow[t]{5}{*}{ Dealer/installation cost: } & equipment cost & 2352 & $56 \%$ \\
\hline & $30 \%$ gross margin & 1008 & $24 \%$ \\
\hline & total equipment & 3360 & $80 \%$ \\
\hline & installation & 840 & $20 \%$ \\
\hline & equipment installed & 4200 & $100 \%$ \\
\hline $\begin{array}{l}\text { End-user cost: } \\
\text { * Furnace size is } 80,000 \mathrm{Btu} / \mathrm{h}\end{array}$ & $\begin{array}{l}\text { equipment installed } \\
\text { output. }\end{array}$ & 4200 & $100 \%$ \\
\hline
\end{tabular}


A common electric heat pump displaced was a mid-efficiency unit (12 SEER) in a replacement application. The cost breakout for this system is as follows.

Mid-efficiency electric heat pump

$\begin{array}{llcc} & & \$ 3-\text { ton } & \% \text { of bottom line } \\ \text { Manufacturer cost: } & \text { equipment cost } & 1456 & 45 \% \\ \text { Distributor cost: } & \text { equipment cost } & 1456 & 45 \% \\ & \text { 20\% gross margin } & 364 & 11 \% \\ & \text { total equipment } & \mathbf{1 8 2 0} & \mathbf{5 6 \%} \\ \text { Dealer/installation cost: } & \text { equipment cost } & 1820 & 56 \% \\ & \text { 30\% gross margin } & 780 & 24 \% \\ & \text { total equipment } & \mathbf{2 6 0 0} & \mathbf{8 0 \%} \\ & \text { installation } & 900 & 20 \% \\ \text { End-user cost: } & \text { equipment installed } & \mathbf{3 5 0 0} & \mathbf{1 0 0 \%} \\ & \text { equipment installed } & 3500 & 100 \%\end{array}$

\section{Commercial Unitary}

The representative gas heat pump cost breakout is provided at the $\$ 1400 /$ ton price point, which corresponds approximately to the price of either engine-driven or absorption rooftop units in the year 1999. The bottom line cost shown is for equipment installed. The $\$ 1400 /$ ton includes setting the unit on an existing roof curb in a replacement application. The hookup costs vary depending on whether a G/E unit is replaced (gas already piped to unit), or an E/E or EHP unit is replaced. Other costs that do not change incremental cost between gas heat pumps and conventional systems (e.g., economizer, indoor ductwork) are not shown.

Commercial gas heat pump rooftop cost breakout

\begin{tabular}{llccc} 
& & \$/7.5-ton & \multicolumn{2}{c}{$\%$ of bottom line } \\
& & & $(\mathrm{G} / \mathrm{E})$ & $(\mathrm{E} / \mathrm{E}, \mathrm{EHP})$ \\
Manufacturer cost: & equipment cost & 4998 & $48 \%$ & $45 \%$ \\
Distributor cost: & equipment cost & 4998 & $48 \%$ & $45 \%$ \\
& 20\% gross margin & 1250 & $12 \%$ & $11 \%$ \\
& total equipment & $\mathbf{6 2 4 8}$ & $\mathbf{6 0 \%}$ & $\mathbf{5 6 \%}$
\end{tabular}




$\begin{array}{lcccc}\text { Contractor/ } & \text { equipment cost } & 6248 & 60 \% & 56 \% \\ \text { installation cost: } & \begin{array}{c}\text { 30\% gross margin } \\ \text { total equipment }\end{array} & 2677 & 25 \% & 24 \% \\ & \mathbf{8 9 2 5} & 85 \% & 80 \% \\ \text { if replacing G/E } & & & \\ \text { equipment } & 8925 & 85 \% & \\ \text { installation } & 1575 & 15 \% & \\ & & \mathbf{1 0 5 0 0} & \mathbf{1 0 0 \%} & \\ & & & 80 \% \\ \text { if replacing E/E or EHP } & 8925 & & 20 \% \\ \text { equipment } & 2222 & & \mathbf{1 0 0 \%}\end{array}$

End-user cost: equipment installed

if replacing G/E $\quad 10500 \quad 100 \%$

if replacing E/E or EHP $\quad 11147 \quad 100 \%$

A common G/E combination displaced by the gas heat pump was the standard gas furnace ( 80 AFUE) with high-efficiency air-conditioner (12.1 EER) in a replacement application. The cost breakout for this system is as follows.

Gas heat/electric cool rooftop cost breakout

$\begin{array}{llcc} & & \$ / 7.5 \text {-ton } & \% \text { of bottom line } \\ \text { Manufacturer cost: } & \text { equipment cost } & 3738 & 46 \% \\ \text { Distributor cost: } & \text { equipment cost } & 3738 & 46 \% \\ & \text { 20\% gross margin } & 935 & 11 \% \\ & \text { total equipment } & \mathbf{4 6 7 3} & \mathbf{5 7 \%} \\ \text { Contractor/ } & & & \\ \text { installation cost: } & \text { equipment cost } & 4673 & 57 \% \\ & \text { 30\% gross margin } & 2002 & 24 \% \\ & \text { total equipment } & \mathbf{6 6 7 5} & \mathbf{8 1 \%} \\ & \text { installation } & 1575 & 19 \% \\ & \text { equipment installed } & \mathbf{8 2 5 0} & \mathbf{1 0 0 \%} \\ & & & \\ \text { End-user cost: } & \text { equipment installed } & \mathbf{8 2 5 0} & 100 \%\end{array}$

A common $\mathrm{E} / \mathrm{E}$ unit displaced by the gas heat pump was the high-efficiency air-conditioner (12.1 EER) model in a replacement application. The cost breakout for this system is as follows, followed by the cost breakout for the electric heat pump rooftop unit. 
Electric heat/electric cool rooftop cost breakout

$\begin{array}{llcc} & & \$ / 7.5-\text { ton } & \% \text { of bottom line } \\ \text { Manufacturer cost: } & \text { equipment cost } & 3528 & 45 \% \\ \text { Distributor cost: } & \text { equipment cost } & 3528 & 45 \% \\ & \text { 20\% gross margin } & 882 & 11 \% \\ & \text { total equipment } & \mathbf{4 4 1 0} & \mathbf{5 6 \%} \\ \text { Contractor/ } & & & \\ \text { installation cost: } & \text { equipment cost } & 4410 & 56 \% \\ & \text { 30\% gross margin } & 1890 & 24 \% \\ & \text { total equipment } & \mathbf{6 3 0 0} & \mathbf{8 0} \% \\ & \text { installation } & 1575 & 20 \% \\ & \text { equipment installed } & \mathbf{7 8 7 5} & \mathbf{1 0 0 \%} \\ \text { End-user cost: } & \text { equipment installed } & 7875 & 100 \%\end{array}$

Electric heat pump rooftop cost breakout

\$/7.5-ton $\quad \%$ of bottom line

$\begin{array}{llcc}\text { Manufacturer cost: } & \text { equipment cost } & 4788 & 47 \% \\ \text { Distributor cost: } & \text { equipment cost } & 4788 & 47 \% \\ & \text { 20\% gross margin } & 1197 & 12 \% \\ & \text { total equipment } & \mathbf{5 9 8 5} & \mathbf{5 9 \%} \\ \text { Contractor/ } & & & \\ \text { installation cost: } & \text { equipment cost } & 5985 & 59 \% \\ & \text { 30\% gross margin } & 2565 & 25 \% \\ & \text { total equipment } & \mathbf{8 5 5 0} & \mathbf{8 4 \%} \\ & \text { installation } & 1575 & 16 \% \\ & \text { equipment installed } & \mathbf{1 0 1 2 5} & \mathbf{1 0 0 \%} \\ \text { End-user cost: } & \text { equipment installed } & 10125 & 100 \%\end{array}$

\section{Chillers}

Water-cooled chiller costs are complicated somewhat by the fact that installed $\$ /$ ton costs vary with size, and the size range of interest is relatively broad. The following table was extracted from a previous study for the Electric Power Research Institute (Energy International 1992), and the costs include chillers, cooling towers, and condenser-side pumps and piping. The triple-effect costs are preliminary estimates from the manufacturers. 


\begin{tabular}{lcccc}
\hline Chiller type & \multicolumn{4}{c}{ Cost by chiller size (\$/ton) } \\
\cline { 2 - 5 } & $>60$ ton & $>100$ ton & $>300$ ton & $>1000$ ton \\
\hline Electric centrigugal/screw & 600 & 500 & 400 & 300 \\
Direct-fired double-effect absorption & & 700 & 600 & \\
Engine-driven chiller & 1000 & 900 & 800 & \\
Direct-fired triple-effect absorption & & 900 & 800 & 600 \\
\hline
\end{tabular}

In general, the current cost premium of double-effect absorption is about $\$ 200 /$ ton, compared with about $\$ 400 /$ ton for engine-driven chillers. When they are introduced, triple-effect chillers are also expected to have a cost premium of about $\$ 400 /$ ton. Double-effect costs are assumed to be about as mature as those of the displaced electric chillers, with the $\$ 200 /$ ton cost premium remaining constant over the 15-year period. However, volume and experience curve effects are expected to reduce the cost premium of triple-effect and engine-driven systems over time ( $\$ 400 /$ ton, $\$ 350 /$ ton, and $\$ 300 /$ ton in the three 5-year periods). The following cost premium breakout is based on $\$ 300 /$ ton, but is representative regardless of cost premium or gas chiller type.

Gas chiller cost premium breakout

\$/ton premium $\quad \%$ of bottom line

$\begin{array}{llcc}\text { Manufacturer cost: } & \text { equipment cost } & 181 & 60 \% \\ \text { Sales related cost: } & \begin{array}{l}\text { equipment cost } \\ 15 \% \text { gross margin } \\ \text { total equipment }\end{array} & 181 & 60 \% \\ \text { Contractor/ } & \mathbf{2 1 3} & 11 \% \\ \text { installation cost: } & \begin{array}{l}\text { equipment cost } \\ \text { installation } \\ \text { chiller installed }\end{array} & 213 & \mathbf{7 1 \%} \\ & \begin{array}{l}\text { incre. tower/ } \\ \text { pump installed }\end{array} & \mathbf{2 5 0} & \mathbf{7 1 \%} \\ & \text { equipment installed } & 50 & 12 \% \\ & \text { equipment installed } & \mathbf{3 0 0} & \mathbf{8 3 \%} \\ \text { End-user cost: } & 300 & 17 \% \\ & & & 100 \% \\ & & & 100 \%\end{array}$


These gas chiller costs are expressed as premiums over electric chillers. No differences in design costs or chiller installation labor costs are expected after the gas industry and manufacturers complete their outreach programs. The cost premium of additional cooling tower and condenser loop pumping and piping is about $\$ 50 /$ ton installed. The rest of the cost premium is the chiller itself.

\section{Life of Gas Cooling Equipment}

In all cases, it is assumed that gas cooling equipment life equals that of the conventional equipment being displaced. Residential and commercial unitary equipment lasts about 15 years (ASHRAE 1987), and chillers last about 30 years (Fischer 1991). 


\section{INTERNAL DISTRIBUTION}

$\begin{aligned} \text { 1. } & \text { P. W. Adcock } \\ 2 . & \text { M. A. Brown } \\ \text { 3. } & \text { G. E. Courville } \\ \text { 4. } & \text { R. C. DeVault } \\ \text { 5. } & \text { P. D. Fairchild } \\ \text { 6-25. } & \text { P. J. Hughes } \\ 26 . & \text { W. A. Miller } \\ 27 . & \text { D. E. Reichle } \\ 28 . & \text { A. C. Schaffhauser } \\ 29 . & \text { R. B. Shelton } \\ 30 . & \text { J. O. Steigler }\end{aligned}$
31. J. J. Tomlinson
32. A. W. Trivelpiece
33. J. VanCoevering
34. D. P. Vogt
35. P. P. Wolff
36. A. Zaltash
37. ORNL Patent Office
38-39. Laboratory Records Department
40. Laboratory Records - RC
41. Central Research Library
42. Document Reference Section

\section{EXTERNAL DISTRIBUTION}

43. J. Abbud, City of Richmond, 600 E. Broad Street, Room 825, Richmond, VA 23219

44. E. Abrecht, Frederick Gas Co., Inc., 924 East Street, P.O. Box 338, Frederick, MD 21701

45. S. H. Ahmed, Alessa Industries, P.O. Box 20409, Riyash, SA 11455, Saudi Arabia

46. W. Albers, Albers Air Conditioning Corp., 7755 S. Research Dr., Suite 123, Tempe, AZ 85284

47. D. Anglin, United Cities Gas Company, 5300 Maryland Way, Brentwood, TN 37027

48. J. Arceri, Consolidated Edison Company, 4 Irving Place, Room 2215, New York, NY 10003

49. R. Aurora, Tecogen, Inc., 45 First Avenue, Waltham, MA 02254-8995

50. R. Aylward, Baltimore Gas \& Electric, P.O. Box 1475, Baltimore, MD 21203

51. M. Baldwin, National Commission for Employment Policy, 1441 L Street, NW, 9000, Washington, DC 20005-3512

52. P. F. Beom, Jr., Hope Gas, Inc., P.O. Box 2868, 215 S. Third Street, Clarksburg, WV 26302-2868

53. R. Best, Transco Energy, 2800 Host Oak Blvd., Houston, TX 77056

54. M. Boatner, Citizens Gas Utility District, P.O. Box 320, Helenwood, TN 37755

55. D. R. Bohi, Resources for the Future, 1616 P Street, NW, Washington, DC 20036

56. B. Boyd, Sierra Power - SRS, 6101 West Courtyard Drive, Bldg. 2, Ste. 225, Austin, TX 78730

57. F. Buchanan, Chipley Gas Department, P.O. Drawer Q, Chipley, FL 32428

58. M. Bunchek, Northern Indiana Public Service Company, 5265 Hohman Avenue, Hammond, IN 46320-1775

59. H. Burrington, Arkansas Western Gas Company, 1001 Sain Street, P.O. Box 1288, Fayeteville, AR 72702-1288

60. M. Byars, Trane, 3600 Pammel Creek Road, La Crosse, WI 54601-7599 
61. D. Caldwell, Chesapeake Utilities Corporation, 1015 6th Street, NW, Winter Haven, FL 33881

62. F. Canada, City of Wilson, P.O. Box 10, Wilson, NC 27893

63. R. Capeslus, Peoples Gas Light \& Coke Co., 122 S. Michigan Ave., Ste. 1105, Chicago, IL 60603

64. J. Carmon, Knoxville Utilities Board, 626 South Gay Street, Knoxville, TN 37950

65. J. Carnahan, Western Kentucky Gas, P.O. Box 866, Owensboro, KY 42302

66. D. Carter, City of Shelby, P.O. Box 207, Shelby, NC 28150

67. J. Causey, Virginia Natural Gas Co., 5100 E. Virginia Beach Boulevard, Norfolk, VA 23502

68. R. Chaney, UGI Corporation, P.O. Box 13009, 225 Morgantown Road, Reading, PA 19610

69. A. Cline, NC Gas Cooling Consortium, c/o City of Lexington, NC, 28 West Center Street, Lexington, NC 27292

70. J. T. Corcoran, FES, 3475 Board Road, P.O. Box 2306, York, PA 17405

71. H. Coss, Baltimore Gas \& Electric, P.O. Box 1475, Baltimore, MD 21203

72. R. Couch, Amoco Production Company, 501 Westlake Park Boulevard, Houston, TX 77079

73. F. Crabtree, Lake Apopka Natural Gas District, P.O. Box 771275, Winter Garden, FL 34777

74. J. Crist, Louisiana Gas Service, 1233 West Bank Expressway, Harvey, LA 70059

75. K. Cuccinelli, Consolidated Natural Gas, CNG Tower, Pittsburgh, PA 15222-3199

76. R. Cullom, Marion Natural Gas System, P.O. Box 408, South Pittsburg, TN 37380

77. J. Daniel, Cookeville Gas Department, P.O. Box 998, Cookeville, TN 38503

78. W. Darby, South Carolina Electric \& Gas, Mail Code K50, Columbia, SC 29218

79. S. Davis, Tallahassee Gas Department, 2602 Jackson Bluff Road, Tallahassee, FL 32304

80. M. Dearing, IMRA America, Inc., 1044 Woodbridge Ave., Ann Arbor, MI 48105

81. H. Deno, Palatka Gas Authority, P.O. Box 978, Palatka, FL 32178

82. S. Desai, Southern California Gas, 555 West 5th Street, ML 25B1, Los Angeles, CA 90013

83. M. Devine, Catepillar, Large Engine, 3701 State Road, 26 East, Lafayette, IN 47905

84. C. Donaldson, City of Madison, 109 SW Rutledge Street, Madison, FL 32340

85. E. Drabek, University of Denver, , Denver, CO 80208-0209

86. A. Dubec, National Fuel Gas Distributrion Corp., 10 Layfayette Square, Buffalo, NY 14203

87. G. Dubois, North Shore Gas Company, 3001 W. Grand Avenue, Waukegan, IL 60085

88. P. Dumouchel, Union Gas Limited, 50 Kell Drive North, Chatham, ON N7M 5M1, Canada

89. R. Durham, Greater Dickson Gas System, 600 E. Walnut Street, Dickson, TN 37055

90. G. Durossette, Greeley Gas Company, 1301 Pennsylvania Street, Ste., 800, Denver, CO 80203

91. T. Easterday, MKW Power Systems, 301 South Church Street, P.O. Box 1928, Rocky Mount, NC 27802-1928

92. R. Eschbacher, Laclede Gas Company, 720 Olive Street, Room 1423, St. Louis, MO 63101 
93. G. Fernstrom, Pacific Gas \& Electric, 123 Mission St., Rm. H-2555, San Francisco, CA 94106

94. J. Ferrantino, Yankee Gas Services Company, 599 Research Parkway, Meriden, CT 06450

95. J. Fischer, SEMCO Inc., 907 Forest Pond Drive, Marietta, GA 30068-4421

96. M. Frevert, Enron Corporation, 1400 Smith Street, EB0659, P.O. Box 1188, Houston, TX 77251-1188

97. J. Furlong, York International, P.O. Box 1592-361R, York, PA 17405-1592

98. M. Garrison, Texas Gas Transmission Company, 3800 Frederica Street, Owensboro, KY 42301

99. H. Geller, American Council for an Energy-Efficient Economy, 1001 Connecticut Ave., NW, Ste., 801, Washington, DC 20036

100. T. Geoffrey, Gainesville Regional Utility District, 3805 NW 97th Boulevard, Gainesville, FL 32605

101. T. Gilles, Lennox Industries, Inc., P.O. Box 799900, Dallas, TX 75379

102. R. Glenn, Roanoke Gas Company, 519 Kimball Avenue, NE, Roanoke, VA 24030

103. M. Goldberg, , 2697 Blucher Valley Road, Sebastopol, CA 95472

104. L. Good, Association of Energy Engineers, Box 1296, Washington Grove, MD 20880

105. I. Gross, ENGELHARD/ICC, 441 N 5th Street, Philadelphia, PA 19123

106. M. Gundersen, Elk River Public Utility District, 217 S Jackson Street, P.O. Box 970, Tullahoma, TN 37388

107. B. Gunter, Jefferson-Cocke County Utility Distirct, 122 Highway 25 East, Newport, TN 38464

108. S. Hall, Dresser Industries - Waukesha Engine Division, 7310 Ritchie Highway, Ste. 316, Glen Burnie, MD 21061

109. S. Harris, PECO Energy Corp., Floor S20-1, P. O. Box 8699, 2301 Market Steet, Philadelphia, PA 19101-8699

110. T. Hawkins, Alabama Gas Corporation, 2101 6th Avenue North, Birmingham, AL 35203

111. W. Hawkins, Consumers Gas Co., P.O. Box 650, Scarborough, ON M1K 5000, Canada

112. B. Helburg, Transcontinental Gas Pipe Line Co., P.O. Box 1396, 2800 Post Oak Blvd., Houston, TX 77251

113. W. Hewlett, City of Live Oak, 101 SE White Avenue, Live Oak, FL 32060

114. S. G. Hildebrand, Oak Ridge National Laboratory, Post Office Box 2008, Oak Ridge, TN 37831-6037

115. R. Hill, Wave Air Corporation, 290 14th Street, Atlanta, GA 30318

116. W. Hoffman, Arkansas Oklahoma Gas Corporation, , Fort Smith, AK 72917

117. M. Holleman, Mississippi Valley Gas Company, P.O. Box 3348, Jackson, MS 39207

118. C. Howell, City of Lake City, P.O. Box 1687, Lake City, FL 32056

119. P. Hufford, GASAIR, P.O. Box 5348, 2302 Golden Pond, Kingwood, TX 77325

120. R. Hulett, Yamaha Motor Company, 6461 Global Drive, Cypress, CA 90630

121. K. Jacobs, Engelhard Corporation, 101 Wood Avenue, Iselin, NJ 8830

122. S. Janke, LaRoche Chemicals, Inc., 1200 Airline Highway, Baton Rouge, LA 70805

123. G. Jennings, Delta Natural Gas Company, 3617 Lexington Road, Winchester, KY 40391

124. T. Judd, American Yazaki Corporation, 13740 Omega Road, Dallas, TX 75244 
125. J. Kearney, Jr., Connecticut Natural Gas Corp., 100 Columbus Blvd., P.O. Box 1500, Hartford, CT 06144-1500

126. L. Klekar, Munters Corporation, 16825 IH 35 North, Selma, TX 78154

127. J. Kott, Middle Tennessee Gas Cooling Consortium, P.O. Box 231, 1036 West Broad St., Smithville, TN 37166

128. M. Kroft, New York State Electric \& Gas, 4500 Vestal Pkwy., East, P.O. Box 3607, Binghamton, NY 13902-3607

129. S. Laden, Southern Union Gas Company, 504 Lavaca, Suite 900, Austin, TX 78701

130-134. S. Laitner, , 1205 Collingwood Road, Alexandria, VA 22308

135. J. Larrison, Citizens Gas \& Coke Utility, 2950 Prospect Street, Indianapolis, IN 46203

136. R. Lee, Laclede Gas Company, 720 Olive Street, Room 1419, St. Louis, MO 63101

137. J. Lewin, Clearwater Gas System, City of Clearwater, 400 North Myrtle Avenue, Clearwater, FL 34615

138. S. Lewis, TRICO Energy Systems, Inc., 3225 Hennepin Avenue East, Minneapolis, MN 55413

139. G. Long, Okaloosa Gas District, 364 Hwy. \#190 E, Valparaiso, FL 32580

140. R. Lopez, Corpoven, FCO, De Miranda, Edlf. Sucre, La Floresta, Caracas, Venezuela

141. W. Lotsberg, Northwestern Public Service Co., Third \& Dakota Ave. South, Huron, SD 57350

142. R. Maki, Cyprus Foote Mineral, 348 Holiday Inn Drive, Kings Mount, NC 28086

143. J. Maney, Kings Mountain Municipal Natural Gas, P.O. Box 429, Kings Mountain, NC 28086

144. P. Mann, Shenandoah Gas, P.O. Box 2440, Interstate 81 at Exit 79, Winchester, VA 22601

145. F. Marino, Trans LA Gas, P.O. Box 4331, Lafayette, LA 70502-4331

146. K. McClatchy, Dunham-Bush, Inc., 101 Burgess Road, Harrisonburg, VA 22801

147. P. McCrary, City of Marianna, P.O. Box 936, Marianna, FL 32446

148. K. McElheny, City of Charlottesville, 305 4th Street, NW, Charlottesville, VA 22903

149. E. J. Mercier, North Carolina Gas Corporation, 150 Rowan St., P.O. Box 909, Fayetteville, NC 28302

150. J. Merckel, ChillCo, Inc., 1971 Abbott Road, Buffalo, NY 14218

151. R. Messera, City of Bessemer City, 132 West Virginia Avenue, Bessemer City, NC 28016

152. D. Moran, American Gas Association, 1515 Wilson Blvd., Arlington, VA 22209

153. J. Morrissey, PSE\&G - Springfield, 24 Brown Avenue, Springfield, NJ 07081

154. B. Mudge, McQuay International, 13600 Industrial Park Blvd., Plymouth, MN 55394

155. F. Muller, Center for Global Change, 7100 Baltimore Ave., Ste. 401, College Park, MD 20740

156. B. Munk, Columbia Gas Distribution Company, 200 Civic Center, Columbus, $\mathrm{OH}$ 43216-0117

157. G. Myers, Gas Research Institute, 8600 West Bryn Mawr Avenue, Chicago, IL 606313562

158. E. Napps, Napps Technology Corporation, P.O. Box 1509, Longview, TX 75606

159. R. Ney, Philadelphia Gas Works, 800 W. Montgomery Avenue, Philadelphia, PA 19122

160. D. Niemiec, Union Pacific Fuels, 801 Cherry St., Fort Worth, TX 76101-0007 
161. J. Null, Herrmidifer, 1812 Colonial Village Lane, P.O. Box 11148, Lancaster, PA 176051148

162. D. O'Neill, Southwest Gas Corp., 5241 Spring Mountain Rd., Las Vegas, NV 891938510

163. L. Pagett, Energas Company, P.O. Box 1121, Lubbock, TX 79408-1121

164. E. Painter, Bluefield Gas Comapny, P.O. Box 589, Bluefield, WV 24701

165. J. Pash, Kathabar Systems, P.O. Box 791, New Brunswick, NJ 08903-0791

166. S. Paskel, Washington Gas Light co., 6801 Industrial Road, Springfield, VA 22151

167. D. Peck, Gas Company of New Mexico, Alavrado Square, Albuquerque, NM 87158

168. S. Phillips, Phillips Engineering Company, 206 Court Street, St. Joseph, MI 49085

169. K. Pittenger, Fayetteville Gas System, P.O. Box 56, Fayetteville, TN 37334

170. W. Plohetski, Michigan Consolidated Gas Company, 500 Griswold Street, Detroit, MI 48226

171. J. Polucha, Valley Gas Company, 1595 Mendon Road, Cumberland, RI 02864

172. D. Pountney, Peoples Gas System, 111 E. Madison Avenue, Tampa, FL 33602

173. G. Ragsdale, Seasons 4, Inc., 4500 Industrial Access Road, Douglasville, GA 30134

174. J. Rankin, Lone Star Gas Company, 301 South Harwood, Dallas, TX 75201

175. D. Rector, Carrier Corporation, 6376 Wavel Street, Syracuse, NY 13206

176. P. Reinhardt, Bay State Gas Company, 300 Friberg Parkway, Westborough, MA 01581 5039

177. T. Richards, Fort Pierce Utility Company, P.O. Box 3191, Fort Pierce, FL 34948

178. R. Rigler, Tenneco Gas, 1010 Milam Street, P.O. Box 2511, Houston, TX 77252-3158

179. V. Roberts, Southern Natural Gas, P.O. Box 2563, Birmingham, AL 35202

180. R. Robinson, Center for Applied Research, 1738 Wynkoop, Ste. 200, Denver, CO 80202

181. D. Salee, Robur Corporation, 2300 Lynch Road, Evansville, IN 47711

182. V. Sanchez, Tokyo Gas - Los Angeles, 633 West 5th Street, Ste. 5880, Los Angeles, CA 90071

183. G. Sandor, FMC Corporation, Lithium Division, 449 North Cox Road, Gastonia, NC 28054

184. I. Sauls, Crescent City Natural Gas, 115 North Summit Street, Crescent City, FL 32112

185. C. Schafer, Northern Illinois Gas Company, 1844 Ferry Road, Naperville, IL 60563

186. M. Scruggs, Municipal Gas Authority of Georgia, 104 Townpark Drive, Kennesaw, GA 30144

187. P. Sharma, Southern California Gas, 555 West 5th Street, Los Angeles, CA 90013

188. W. Sherk, City of Rocky Mount, P.O. Box Drawer 1180, Rocky Mount, NC 27802

189. N. Sherman, Aerojet, 1100 W. Hollyvale Street, Azusa, CA 91702

190. N. Sidler, Peoples Gas Light \& Coke Co., 122 South Michigan Avenue, Chicago, IL 60603

191. R. Smith, Florida Public Utilities Company, 401 South Dixie Highway, West Palm Beach, FL 33401

192. R. Smith, Peoples Natural Gas Co., 625 Liberty Avenue, Pittsburgh, PA 15222

193. G. F. Sowers, Law Companies Group, Inc., 114 Townpark Drive, Ste. 250, Kennesaw, GA 30144-5599

194. M. Standley, DeFuniak Springs Natural Gas, P.O. Box 685, DeFuniak Springs, FL 32433 
195. J. Stanley, Public Service North Carolina, P.O. Box 1398, 400 Cox Road, Gastonia, NC 28053-1398

196. J. Stauder, Briggs and Stratton, 3560 North 124th Street, Dock 20, Milwaukee, WI 53222

197. J. Stephens, Southwest Gas Corp., P.O. Box 98510, 5241 Spring Mountain Road, Las Vegas, NV 89193-8510

198. J. Sullivan, Atlanta Gas Light Company, P.O. Box 4569, Atlanta, GA 30302

199. R. S. Sweetser, American Gas Cooling Center, 1515 Wilson Blvd., Arlington, VA 22209

200. P. Swenson, Consolidated Natural Gas, 625 Liberty Avenue, Pittsburgh, PA 15222

201. B. Swiecicki, National Propane Gas Association, 1600 Eisenhower Lane, Ste. 100, Lisle, IL 60532

202. W. Syniuta, Advanced Mechanical Technology, Inc., 176 Waltham Street, Watertown, MA $02172-4800$

203. A. Tarrant, Lone Star Gas Company, 301 South Harwood, Dallas, TX 75201

204. R. Thompson, Rotary Power International, Inc., P.O. Box 128, Wood-Ridge, NJ 07075

205. T. Thornton, City of Monroe, P.O. Box 69, Monroe, NC 28110

206. T. Tower, The East Ohio Gas Company, 1717 East Ninth Street, Cleveland, OH 44114

207. M. Tran, Piedmont Natural Gas Co., 1915 Rexford Road, Charlotte, NC 28211

208. R. Tugwell, Greenville Utilities Commission, P.O. Box 1847, Greenville, NC 27835

209. F. Verbeke, Alturdyne, 8050 Armour Street, San Diego, CA 92111

210. K. Darrow, Energy International, 127 Bellview Way, SE, Ste. 200, Bellview, WA 980046229

211. R. Gadley, Energy Ventures Analysis, Inc., 1901 N Moore St., Ste. 1200, Arlington, VA 22209-1706

212. T. DuBois, EE-422, FORS, Washington, DC 20585

213. Ms. Vuchetich, West Ohio Gas, 319 W. Market, Lima, OH 45801

214. C. M. Walton, University of Texas at Austin, Department of Civil Engineering, Austin, TX 78712-1076

215. A. Ward, McQuay International, 13600 Industrial Park Blvd., Minneapolis, MN 55441

216. D. Warner, Utility Systems Florida, Inc., 777 South Flagler Drive, Ste. $800 \mathrm{~W}$, West Palm Beach, FL 33401

217. C. Warrington, Clearwater Gas System, City of Clearwater, 400 North Myrtle Avenue, Clearwater, FL 34615

218. R. Watkins, Industry Lialson Consultant, 301 Rosemary Lane, Gastonia, NC 28054

219. J. Welch, Equitable Resources, Inc., Allegheny Cente Mall, Ste. 2000, Pittsburgh, PA $15212-5352$

220. D. Wilkersen, ARKLA, P.O. Box 751, Little Rock, AR 72203

221. S. Williams, Indiana Gas Company, 1630 N. Meridian St., Indianapolis, IN 46202

222. H. Zehender, Sunrise Gas System, 4747 Nob HIll Road, Ste. 5, Sunrise, FL 33351

223. J. Zook, Atmos Energy Corporation, P.O. Box 650205, Dallas, TX 75265

224. Office of the Assistant Manager for Energy R\&D, U.S. Department of Energy, Oak Ridge Operations, Oak Ridge, TN 37831-6269

225-226. Technical Information Center, Department of Energy, Post Office Box 62, Oak Ridge, TN 37831 